Volume 9, Issue 2 (Summer 2017)

\title{
Sensory Piety as Social Intervention in a Mechelen Besloten Hofje
}

Andrea Pearson

pearson@american.edu

Recommended Citation:

Andrea Pearson, "Sensory Piety as Social Intervention in a Mechelen Besloten Hofje," Journal of Historians of Netherlandish Art 9:2 (Summer 2017) DOI: 10.5092/jhna.2017.9.2.1

Available at https://jhna.org/articles/sensory-piety-social-intervention-mechelen-besloten-hofje/

Published by Historians of Netherlandish Art: https://hnanews.org/

Republication Guidelines: https://dev.jhna.org/republication-guidelines/

Notes: This PDF is provided for reference purposes only and may not contain all the functionality or features of the original, online publication. This PDF provides paragraph numbers as well as page numbers for citation purposes.

ISSN: 1949-9833 


\title{
Sensory Piety as Social Intervention in a Mechelen Besloten Hofje
}

\author{
Andrea Pearson
}

Besloten hofjes compel sensory devotion, and sight provides the privileged point of entry into the works. Paradoxically, a female devotee from Mechelen, identified here as visually impaired, is represented in a wing hinged to one example. By prioritizing physical disability over spiritual interiority in the study of the hofje, this essay recalibrates sensory piety as socially persuasive. The investigation in turn complicates previous models for the production and reception of Bes/oten hofjes in general.

Previously untapped archival and visual evidence reveals that the hofje was likely commissioned by the impaired woman's parents, probably for the Onze-Lieve-Vrouwegasthuis (Hospital of Our Lady) in Mechelen, where she was professed. There, the hofje asserted a meritorious status in piety that claimed salvation for members of the familial triad, all three of whom were rendered spiritually suspect by the woman's disability. It does so in part by invoking pious practices tied not to sight but to the other senses, despite the visual pull of the work. Furthermore, integrating the hofje's portrait wings interpretively with a garden, as this essay is the first to do, opens a new means of analysis that reshapes proposed models of production for such works. Among its conclusions: the sisters did not produce this and other hofjes associated with the Onze-Lieve-Vrouwegasthuis as previously proposed. Rather, the works were likely made in professional workshops in Mechelen that perhaps collaborated with nuns at contemplative convents in the city. This revised understanding of production realigns the hospital sisters' agency with reception rather than production.

Besloten hofjes demand close looking. Composed of upright cabinets brimming with handwrought flora, fauna, and fruit arranged in verdant gardens, these lush topographies become visually and conceptually intelligible only though careful observation (fig. 1). Among the information gleaned from such vigilance is that the cabinets are embellished by relics (fig. 2). ${ }^{1}$ These fragments of "holy matter" complement the sculptures of saintly figures that dominate the gardens, sanctifying 


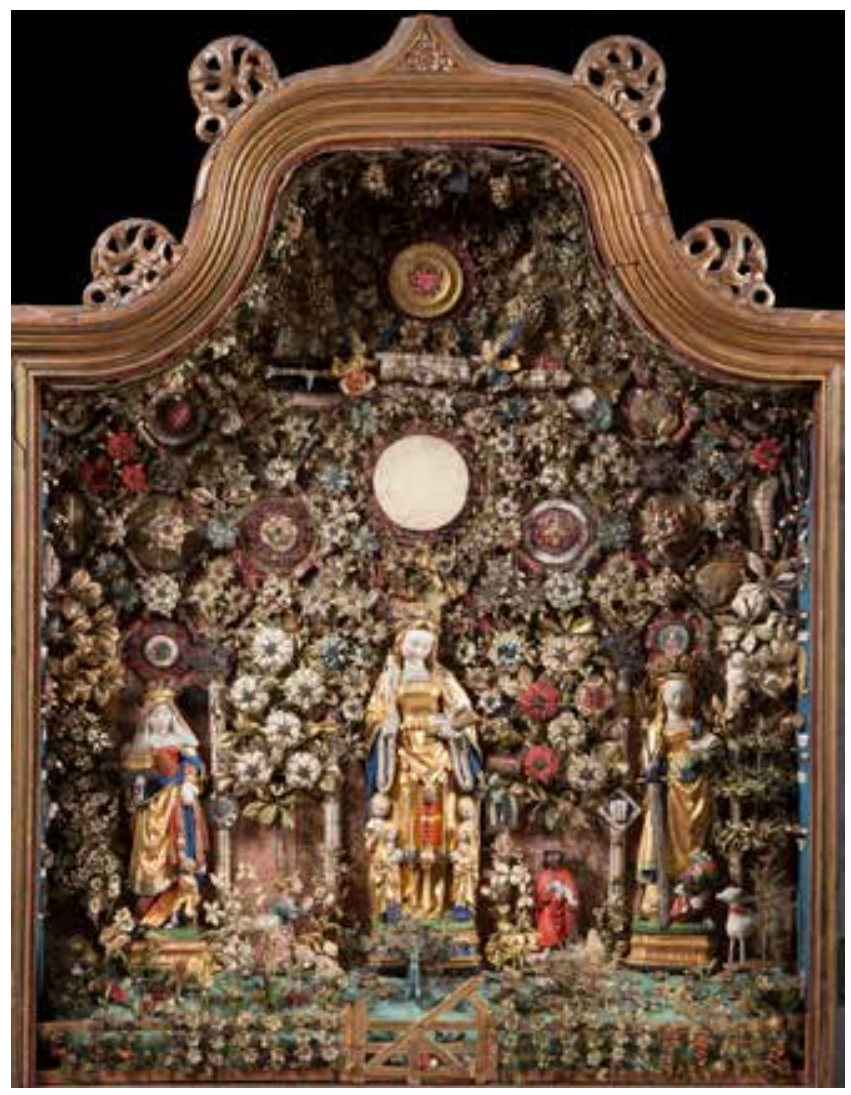

Fig. 1 Mechelen, Besloten Hofje with Saint Elizabeth of Hungary, Saint Ursula, and Saint Catherine of Alexandria, 1513-24 (?) (center cabinet), polychromed wood, silk, paper, bone, wax, wire, and other materials in a wood case, $134 \times 97.5 \times 22.2 \mathrm{~cm}$. Musea \& Erfgoed Mechelen, inv. GHZ BH/2, Collectie Gasthuiszusters, Onze-Lieve-Vrouw Waver, @ KIK-IRPA, Brussels, www.kikirpa.be on long-term loan from the Augustinian Sisters of Mechelen (artwork in the public domain)

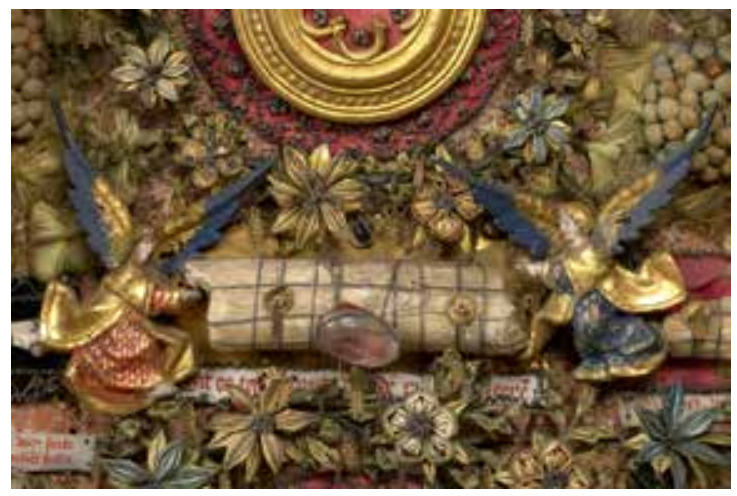

Fig. 2 Bone relic of the 11,000 virgin martyrs labeled, "This comes from the bones of the 11,000 martyred [virgins] (Dit es tghebennte vande[n] xim merteleere[n])" (detail of fig. 1), @ KIK-IRPA, Brussels, www.kikirpa.be, cliché X002679, photo: Jean-Luc Elias

the fictive terrain and clarifying the devotional intent of the works. Further observation reveals that the hofjes share a particular thematic emphasis. Running along the lower foreground in most examples are fences made of wood, paper, or fabric, which are usually punctuated by gates (fig. 3). This feature points to a specific passage from the Song of Songs that was interpreted by medieval theologians as a reference to the Virgin Mary's purity: "a garden enclosed, sister my bride/a garden enclosed, a fountain sealed" (4:12). ${ }^{2}$ The descriptive title Besloten hofjes (enclosed gardens) was assigned to the works by art historians who picked up on this connection. ${ }^{3}$ However, even as a hofje's fence marks the garden as impenetrable, the rich array of dense minutiae all but obligates visual entry. It also invites a measured ocular pace: the eye may quicken momentarily across the varied forms, yet the cabinet's remarkable content soon compels it to linger. This meticulous way of looking ostensibly sharpened the beholder's spiritual focus and prolonged the meditative activity. ${ }^{4}$ The result: a more intimate and efficacious devotional experience.

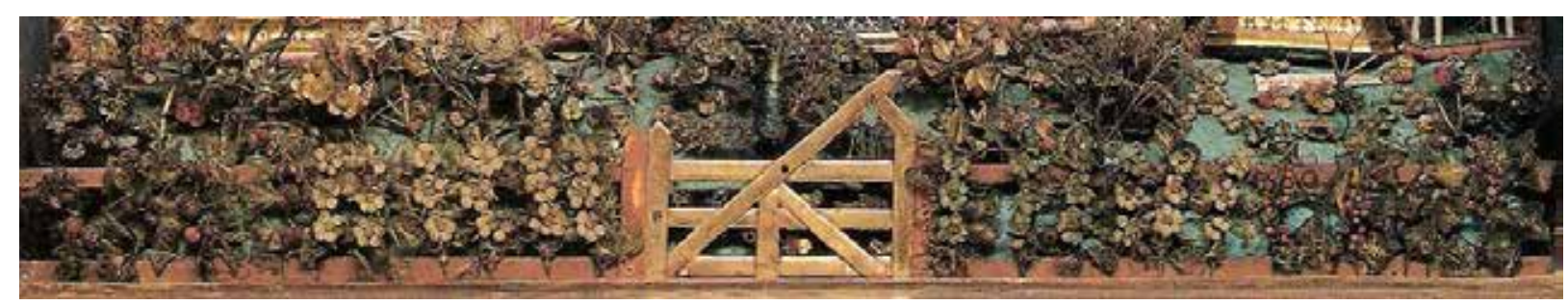

Fig. 3 Detail fig. of 1.

2 If Besloten hofjes are visually insistent and visually rewarding in devotion, a detail from an 
example produced in the early modern Low Countries seems at odds with this premise. A woman kneeling in prayer in one of two portrait wings attached to the work (fig. 4) is depicted with her eyes closed and with malformed ocular orbits (fig. 5), most likely to indicate that she is blind, or at the very least visually impaired. ${ }^{5}$ This condition would have necessarily precluded her from entering the hofje's garden visually, from engaging ocularly with the garden's botanical elements and relics. She could neither see the sculptures of the holy figures that populate it-in this case Saint Elizabeth of Hungary, Saint Ursula, and Saint Catherine of Alexandria-nor reap by sight the spiritual rewards promised through meditation on its rich landscape and hallowed content.

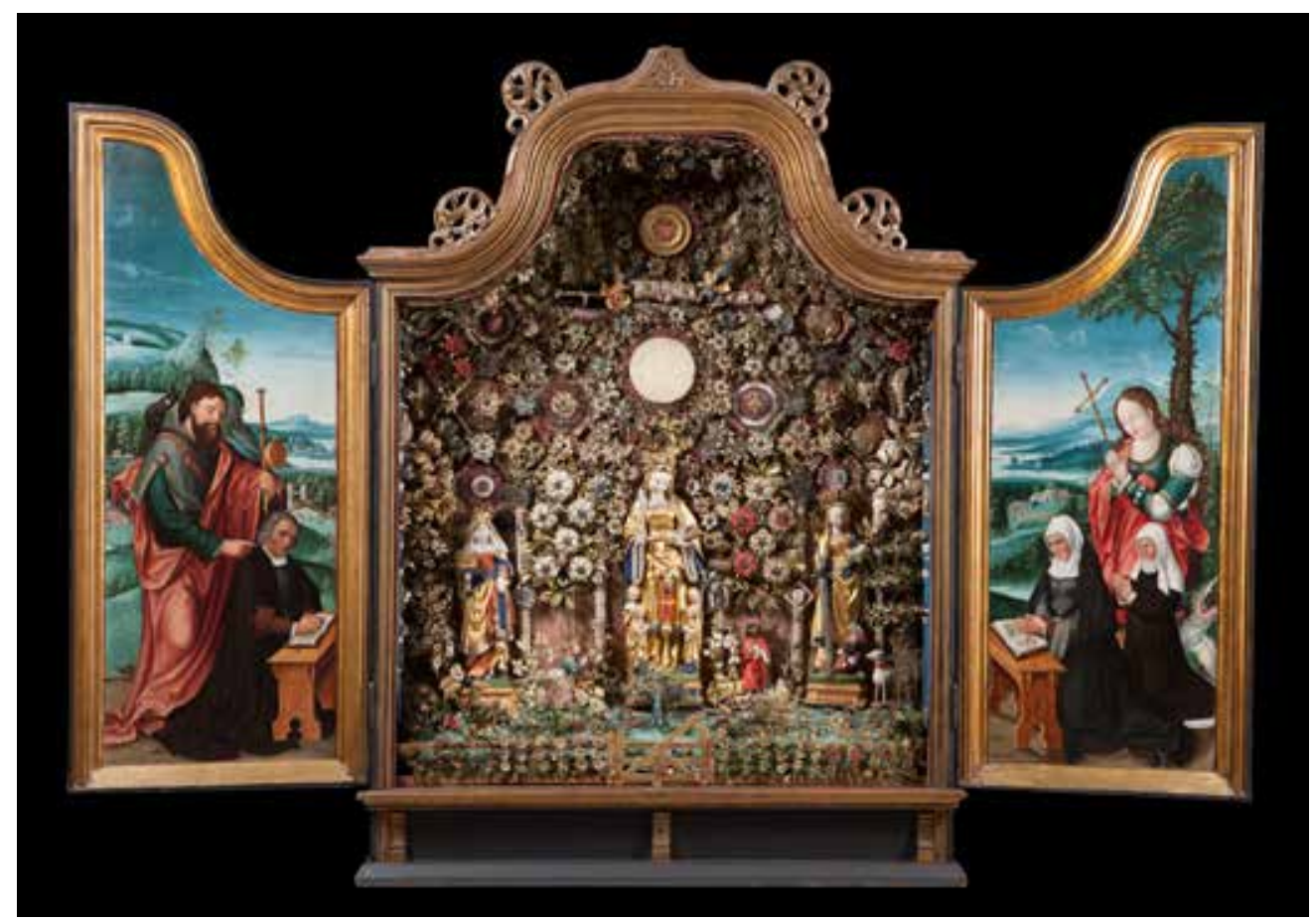

Fig. 4 Overview of center cabinet (see fig. 1) and wings, oil on panel, $134 \times 188.5 \times 22.2 \mathrm{~cm}$.

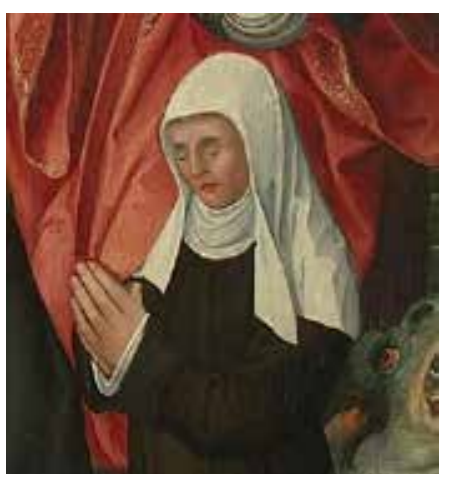

Fig. 5 Right-hand wing (Maria Van den Putte) (detail of fig. 4), ( ) KIK-IRPA, Brussels, www.kikirpa.be, cliché X002660, photo: Jean-Luc Elias

The depiction of a visually disabled person in the wing of a hofje provides a rare opportunity to consider in tandem the sometimes conflicting socio-religious views of disability in the sixteenth century and the social experiences of disabled people. Historians of disability in the early modern world are in fact calling for new studies that unite metaphor with practice in this way. ${ }^{6}$ This approach is taken up here, while also setting in motion a new line of inquiry for Besloten hofjes on the whole: the socio-spiritual resonances of the works have yet to be considered, despite the presence in some key examples of portrait wings that invite it. Indeed, portraits have yet to be integrated interpretively with any of the hofjes that have them. Two other investigative paths have arisen instead. One attends to the spiritual meaning of the gardens and the other addresses the 
works' production and quality. As for the former, Paul Vandenbroeck, in his essay for the exhibition catalogue Hooglied: De beeldwereld van religieuze vrouwen in de Zuidelijke Nederlanden, vanaf de 13de eeuw (Enclosed garden: The imagination of religious women in the southern Low Countries since the thirteenth century) published in 1994, explored the relationship of enclosed gardens to notions of the soul, paradise, and expectations for conventual enclosure. ${ }^{7}$ That essay and others in the catalogue, by Luce Irigaray, Julia Kristeva, and Birgit Pelzer, were largely psychoanalytic in approach. This method was taken up again later by Barbara Baert. In an article published in 2009, Baert argued that female beholders could circumvent the patriarchal tethers of monasticism by meditating on the hofjes' dense imagery and potent relics. ${ }^{8}$ More recently, she proposed a "new, multiple hermeneutics" for the hofjes that defines the gardens as, in part, "psychic location[s] of the indescribable membrane within chthonic art." Alternatively, in light of the turn toward the material in the humanities, Kathryn M. Rudy argued that the sensory experiences evoked by convent hofjes containing Crucifixions and Holy Land relics made the passion of Christ more immediate for nuns who were unable to travel and could only experience pilgrimages mentally. ${ }^{10}$

4 The second thread in the scholarship, on artistic production and qualitative discernment, attributes the complex floral elements and wrapped relics of the gardens, wrought by hand from various materials, including silk, paper, and wire, to nuns, including the Augustinian sisters at the Onze-Lieve-Vrouwegasthuis (Hospital of Our Lady) in Mechelen. In this scenario, the sisters created the handwork elements for the hofjes in their possession, installed them in the cabinets, added sculptures produced serially in workshops in the city of Mechelen (most sculptures in the hofjes are stamped with Mechelen makers' marks, including those in the one investigated here ${ }^{11}$ ), and contracted with local artists, whose names remain unknown, to paint the wings. ${ }^{12}$ By contrast, Horst Appuhn argued that the hofjes' decorations are of such high technical achievement that they must have been manufactured serially, in a professional setting. ${ }^{13}$ Hartmut Krohm supports this position but proposes that nuns at Mechelen convents, including those at the Onze-Lieve-Vrouwegasthuis, produced the adornments for a hofje industry that stretched across the urban landscape. ${ }^{14}$ Dagmar Eichberger carries this discussion into matters of taste with hofjes owned by Margaret of Austria, regent of the Netherlands whose governmental seat and residence were in Mechelen, a discerning patron and collector of the visual arts. ${ }^{15}$

5 The present study, by contrast, begins the process of interpreting the gardens together with their portrait wings as a means of exploring the social dynamics of Besloten hofjes. The example depicting the blind woman, and most other Netherlandish hofjes with preserved portraits, were formerly in the possession of the Onze-Lieve-Vrouwegasthuis in Mechelen. ${ }^{16}$ A total of seven hofjes from the hospital are known, four with extant portrait wings. This is the largest group of hofjes associated with any particular community in the southern Low Countries. ${ }^{17}$ (The Mechelen hofjes hold exceptional cultural value in contemporary Belgium: in 2011 they were added to the list of Vlaamse Topstukken [Flemish masterpieces] that includes such canonical works as Jan van Eyck's Ghent Altarpiece.) The flora, fauna, and fruit of the hofjes necessarily implicate sensory devotion in every case, yet the example with the blind woman does so under very specific circumstances that merit close scrutiny in relation to her condition. As will become evident, the work invokes for its audiences not just the sense of sight but the other senses as well, in ways that cast the impaired sister as a spiritually-abled member of her religious community despite her impairment. 
Ultimately this and other conclusions offered here lend substance to an underexplored premise in Netherlandish devotional art: sensory piety as social intervention. ${ }^{18}$ I will make three main points along this line. First, the figures represented by the portraits can be reasonably identified using previously untapped visual and archival evidence. They are individuals who resided in Mechelen in the early sixteenth century: Jacob Van den Putte, his wife Margaretha Svos, and their visually disabled daughter Maria Van den Putte. I will argue that Jacob and Margaretha commissioned the hofje to mediate positively with the community - the hofje's provenance with the Onze-Lieve-Vrouwegasthuis strongly suggests the work's presence there from its inception-on behalf of themselves and their disabled daughter, whose blindness rendered all three spiritually suspect. In so doing, they laid claim in the hospital context to charitable and pious practices that merited Maria's acceptance into the profession as well as her and her parents' salvation. For Maria in particular, the hofje claimed devotional understanding not through the privileged sense of sight, despite the garden's visual pull, but rather by multisensory devotion and the possibilities for healing implied by the hofje's content. Second, the hofje reminded the hospital sisters of their commitment to Maria, whose presence carried an expectation of lifelong care that was in addition to their supervision of an already demanding public infirmary. Jacob and Margaretha may have had reason to worry about the quality of that care, since the hospital had a history of resisting reforms that required a renewed commitment to the infirm. Accepting Maria as a professed sister benefitted the community in a crucial way, however, for it imbedded the sisters more securely into a spiritual economy considered advantageous to the bodily abled and disabled alike. Finally, I will build contextual evidence into previous writings about the serial fabrication of the floral adornments in order to recast the hofje from a presumed product of the sisters' labor (the garden) and patronage (the painted wings) to one of professional manufacture. This conclusion bears not only upon the particular hofje under investigation here but also upon the intersections of lay and monastic piety and religious women's art-making activities in the early modern Low Countries.
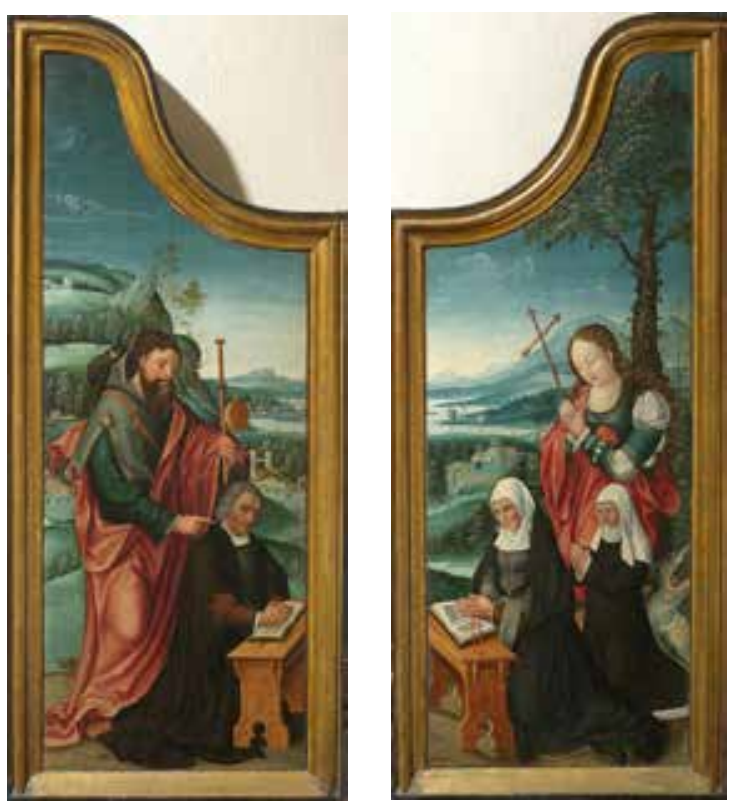

Fig. 6-left Left-hand wing (Jacob Van den Putte with Saint James the Greater) (detail of fig. 4), (c KIK-IRPA, Brussels, www.kikirpa. be, cliché X002659, photos: Jean-Luc Elias

Fig. 6-right Right-hand wing (Margaretha Svos and Maria Van den Putte with Saint Margaret of Antioch) (detail of fig. 4), (C) KIK-IRPA, Brussels, www.kikirpa.be, cliché and X002660, photos: Jean-Luc Elias 


\section{Portraits, Patrons, and Audiences}

$7 \quad$ Visual evidence culled from the hofje's wings nullifies a supposition about the depicted figures that has persisted in the scholarship for over a century. These writings insist that the two women on the right-hand wing were sisters professed at the Onze-Lieve-Vrouwegasthuis in Mechelen and that the man on the left was their priest (fig. 6 left, fig. 6 right). ${ }^{19}$ Yet the male and female figures closest to the garden are depicted not in habits that would convey monastic status but rather in lay attire: both wear fur-lined garments over brocade. Furthermore, the woman's form is laden with luxury objects. A belt around her waist terminates in a gold buckle, and she wears a gemmed ring and holds a rosary of coral and gold beads punctuated by a gold cross. Rich bodily adornments of this kind were in fact prohibited at the hospital by statutes of reform that were enforced starting in 1509. ${ }^{20}$ By contrast, the female figure on the far right is not rendered in luxury fabrics and furs; neither is she portrayed with forbidden sartorial adornments or opulent devotional aids. Rather, she appears in the simple dark habit and white wimple described in the statues. This figure must therefore represent a professed sister, as has been maintained. But what, then, is the relationship of these figures to one another? Early Netherlandish conventions for portraiture strongly suggest that the lay figures are a married couple and the nun is their daughter. ${ }^{21}$ Many examples of this type of triptych representing spouses and their children were produced in the early modern Netherlands. A well-known example by Hans Memling, dating to 1484 (fig. 7), depicts Willem Moreel and Barbara Van Valenderberch with sixteen of their eighteen children. Visual evidence for the relationships of the figures in the hofje strongly suggests that it too is a family triptych. The wrinkled brows, sagging jowls, and crow's feet of the hofje's male and principal female figures signal middle age. The nun bears no such telltale signs, however, and she appears comparatively younger than her lay companions. These pictorial features seem intent on conveying a parent-child relationship by point of contrast.
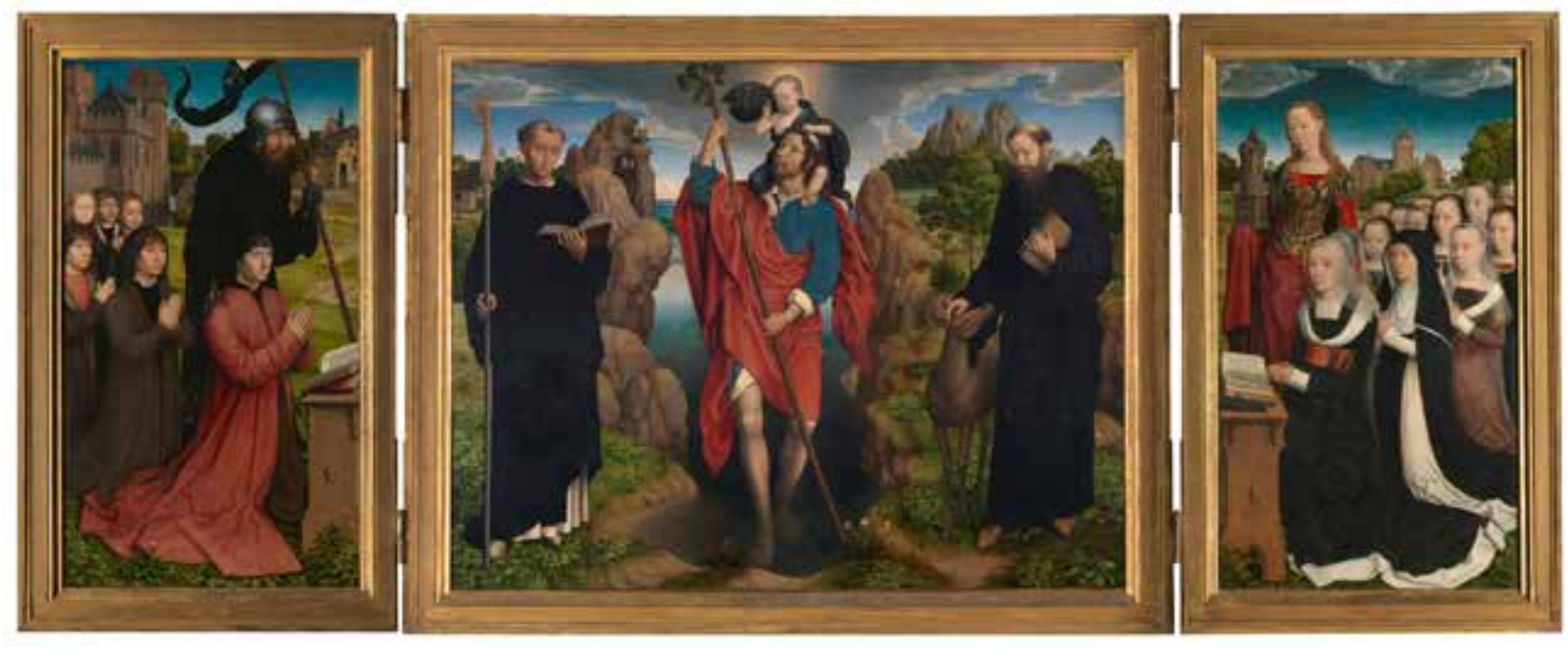

Fig. 7 Hans Memling, Triptych of Willem Moreel and Barbara Van Valenderberch, 1484, oil on panel, (center) 141 x $174 \mathrm{~cm}$, (wings) 141 x $87 \mathrm{~cm}$. Bruges, Groeninge Museum, 0000.GR00091.I-0095.I , @ Lukas - Art in Flanders VZW, photo Hugo Maertens, https://creativecommons.org/licenses/ by-nc-nd/4.0/legalcode (artwork in the public domain)

The figures in the hofje's wings can be identified as individuals who resided in Mechelen in the early sixteenth century. The evidence is both iconographical and archival. Starting with the for- 
mer, in all probability the married couple share their given names with the saints with whom they are shown - their patron saints - as was customary in Netherlandish portraiture of the period. ${ }^{22}$ In the case of the hofje, the saints are James the Greater and Margaret of Antioch, as determined by the figures' attributes: pilgrim's attire for James and a dragon for Margaret. The layman's name was therefore James or Jacob, and the laywoman's Margaret or Margaretha. Preserved at the Stadsarchief in Mechelen are three documents from the hospital's archive in which the names Jacob and Margaretha appear together in ways that signify marriage. They all pertain to the same two individuals, namely, Jacob Van den Putte and Margaretha Svos. Jacob and Margaretha lived on Hanswijkstraat at the corner of Potterijstraat, a short walk from the hospital, on Onze-Lieve-Vrouwestraat (fig. 8). ${ }^{23}$ Jacob Van den Putte coadministered the Heilige Geesttafel (Confraternity of the Holy Spirit), a charitable organization at the nearby priory of Hanswijk: with one Jacob de Vos, he supervised its revenues, as recorded in a bound volume, dated 1523, also at the Stadsarchief. ${ }^{24}$ The three documents in the hospital's archive that pertain to the couple address matters of their estate while incidentally identifying by name the second female figure depicted in the hofje. The first, a will for the couple dated April 9, 1524, provides for their daughter, Maria Van den Putte, who is described as a professed sister at the hospital. ${ }^{25}$ The second, a testament from April 9, 1527 [1528], arranges for each of the couple's three children to receive an equal share of their estate upon their deaths. ${ }^{26}$ The third, an entry in the hospital's financial register from 1541, states that the community had come to own a share in Margaretha and Jacob's house through inheritance from Maria. ${ }^{27}$ When considered together, the evidence for patterns of portraiture in Netherlandish familial triptychs and the content of the documents pertaining to Van den Putte and Svos leave little doubt that the hofje depicts Jacob, Margaretha, and their professed daughter Maria.

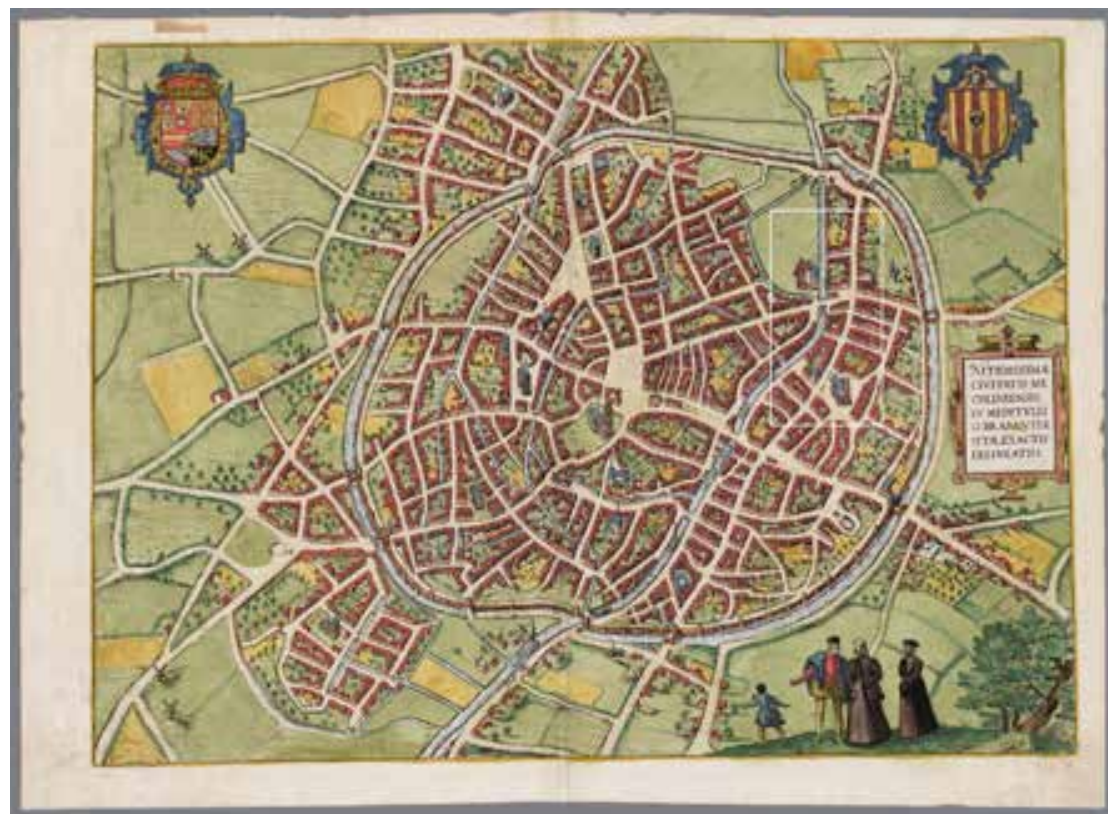

Fig. 8 G. Braun and F. Hogenberg, Plan of the City of Mechelen, from Civitates Orbis Terrarum, Liber primus (Cologne, 1574) Mechelen, Stadsarchief, beeldbankmechelen.be, B.6522

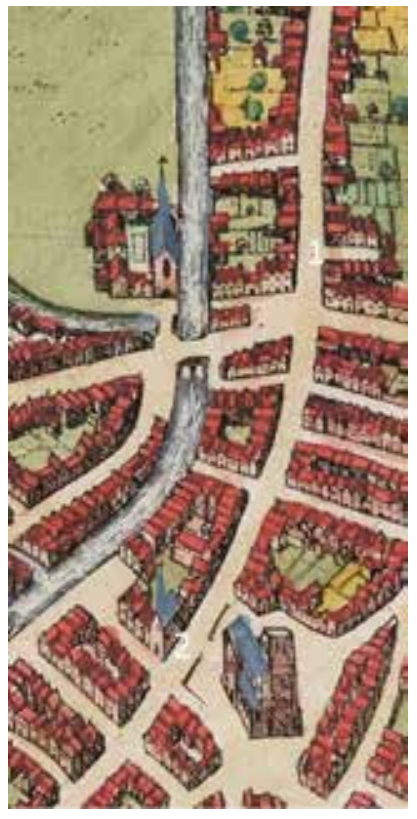

Fig. 8-detail, Residence of Jacob Van den Putte and Margaretha Svos, on Hanswijkstraat at the corner of Potterijstraat. 2) Onze-Lieve-Vrouwegasthuis. Mechelen, Stadsarchief, beeldbankmechelen.be, B.6522 
While the hospital's archive has yielded important evidence about the persons portrayed in the hofje's wings, it is frustratingly silent about other key issues. Among these are the patronage and production of the work, its entry into the Onze-Lieve-Vrouwegasthuis, and its mode of display and use. ${ }^{28}$ These issues can be explored through other means, however. For example, what we know about the patronage of family triptychs in the early modern Low Countries strongly suggests that Jacob Van den Putte and Margaretha Svos commissioned the work: they appear in the positions and attitudes normally assigned to patrons in family diptychs, such as those in Memling's Moreel/Valenderberch triptych. Furthermore, the hofje's hospital provenance and Maria's depiction as a professed sister at the community, as indicated by her habit, make it likely that Jacob and Margaretha commissioned the work for that context, where it functioned both devotionally and socially.

10 The depiction of lay supplicants Jacob and Margaretha in the wings of the hofje in the positions and attitudes conventionally reserved for patrons also throws into doubt the enduring premise that the sisters of the Onze-Lieve-Vrouwegasthuis commissioned the shutters. (The painter(s) for these and other wings from the Mechelen hofjes remains a mystery: presuming local production, guild records for Mechelen that could have helped to resolve this problem do not survive for this period.) It hardly seems possible that the nuns would collectively order wings that represent lay supplicants in a conventional family arrangement for a devotional work they ostensibly intended to keep at the hospital. Neither is it likely that Maria (or another sister) did so independently, since one's profession usually if not always limited the resources that would enable such activity. The patronage of the wings by Jacob and Margaretha suggests in turn that they commissioned not only the panels but the work as a whole.

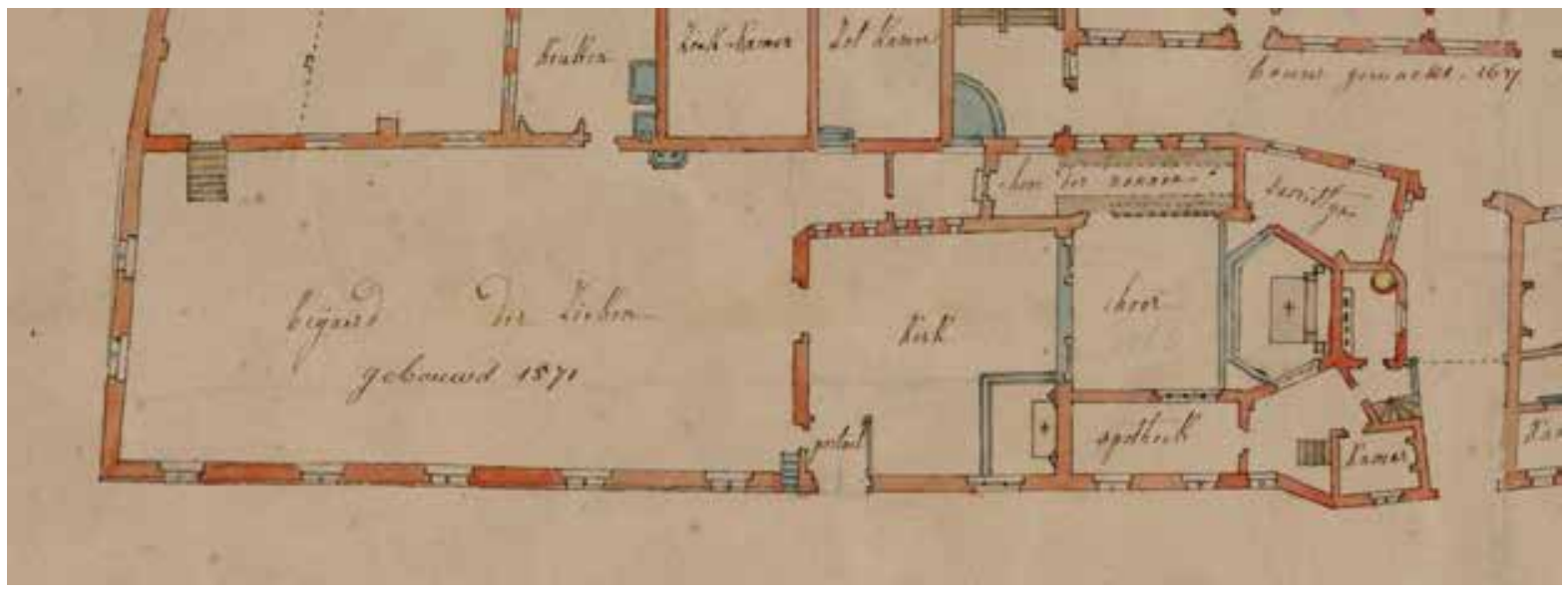

Fig. 9 Plan of Onze-Lieve-Vrouwegasthuis, Mechelen (detail). Mechelen, Stadsarchief, beeldbankmechelen.be, iconografische verzameling C 8018.

11 Certainly the arrival of the hofje at the hospital would not have escaped notice. The visual pull and thematically sanctified nature of the garden would compel attention at that moment; its themes intersect with those of conventual devotional literature, cited below, in ways with which the sisters likely identified. It also seems probable that the hofje was visually accessible to the professed sisters at large. This and other hofjes in the hospital's possession could have been installed in several different spaces within the built environment. That environment was de- 
molished in the 1860s when the sisters moved to a modern facility, yet it can be at least partially understood through a plan made in 1857 after an earlier one, from 1784 (fig. 9). The plan illustrates a nun's choir ("choor der nonnen") adjacent to a choir proper, which opened up onto the church. The latter space was accessible to the public and visible from the infirmary. However, I would suggest that the depiction of the blind sister in the hofje was perhaps too intimate for the publicly accessible areas of the hospital. It seems more plausible that it was installed in the nuns' choir or in spaces reserved expressly for the sisters, where images might be kept, such as in their refectory: the statutes of reform state that a sculpture was located there. ${ }^{29}$ Whatever the case, the work was likely regularly if not consistently visible to the sisters. Jacob and Margaretha must have depended upon that access to enable a communicative role for the imagery: as argued here, the hofje makes spiritual claims for them and for Maria, while also reminding Maria's sisters about their commitment to her care as a disabled person.

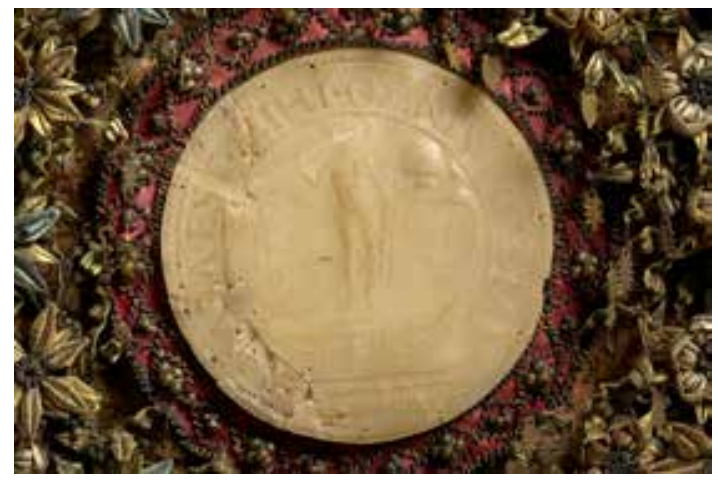

Fig. 10 Wax medallion with the Resurrection, dated 1513 (detail of fig. 1), @ KIK-IRPA, Brussels, www.kikirpa.be, cliché X002683, photo: Jean-Luc Elias

12 Evidence for the date of the hofje's production and, by extension, its arrival at the hospital can also be gleaned from the work. A wax medallion at the upper center of the garden (fig. 10), dated 1513 , is integrated so deeply into the adjacent flora and fauna that it could not have been a later addition. The terminus post quem for the hofje is therefore 1513. Nor could the work have been commissioned after 1541, the date of the hospital's financial register that describes Jacob and Margaretha as deceased. If the two presented the hofje to the hospital as proposed, perhaps they did so at the time of Maria's profession, which occurred in or before 1524, when she is described in her parents' will as professed. If so, the hofje was made between 1513 and 1524.

\section{Sight, Sightlessness, and Suspicion}

13 Maria's closed eyes render her figure exceptional among Netherlandish devotional portraits of the fifteenth and early sixteenth centuries. In only three of the 707 Netherlandish devotional portraits surveyed by Ingrid Falque are figures depicted in this way. ${ }^{30}$ They are clerics and nuns, as evidenced by their religious habits. These unusual renderings may convey for the figures a deeper spiritual skill-set than the lay devotees shown with them, ${ }^{31}$ who gaze up at Christ or saints or down at prayer books. Such a reading initially seems plausible in Maria's case, for her devotional skill was of considerable concern, as we will see. Yet the closed eyes in these four portraits, and perhaps especially Maria's, may in fact convey something else: visual impairment. Indeed, by the fifteenth century closed eyes had become a common pictorial convention for blindness. Examples abound across artistic media, in panel painting and manuscript illumination, 
and also in single-sheet prints and printed books that circulated widely. For now, I highlight three such works to be discussed in greater detail below, along with additional examples. The first is a woodcut from a printed version of Ludolph of Saxony's Speculum vitae Christ, translated by the late fifteenth century into Dutch as Tboeck vanden leven ons heeren Jesu Christi (The book of the life of our Lord Jesus Christ), that shows Christ healing a mad man and two blind men; the latter figures' eyes are shut to convey visual impairment (fig. 11). ${ }^{32}$ Second, the Master of Alkmaar's Polyptych with the Seven Works of Charity of 1504 (fig. 12) portrays a shut-eyed blind man seeking alms, whose forward movement is guided by a child strapped to his head (fig. 13). Third, some images of the Crucifixion include the Roman soldier, later called Longinus, who disavowed Christ by piercing his side (John 19:34-35) and whose sightless status prevented him from seeing the divine truth; Christ's blood restored his sight. In a Crucifixion painted in Utrecht around 1505 (fig. 14), Longinus points to the closed eyes that signaled his blindness, to ask for assistance in raising his lance to pierce Christ's side. ${ }^{33}$

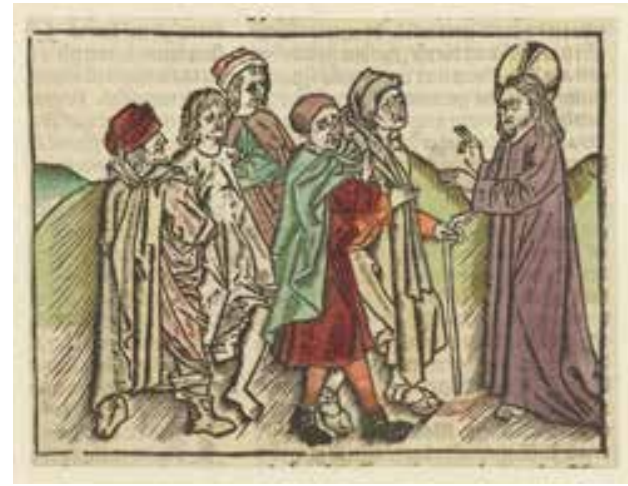

Fig. 11 Attributed to the Master of Antwerp, Christ Heals Two Blind Men and a Mad Man, from Ludolph of Saxony, Tboeck vanden leven ons heeren Jesu Christi (The book of the life of our Lord Jesus Christ) (Zwolle (?), 1485-91). Hand-colored woodcut, 9.2 x $12.4 \mathrm{~cm}$. Amsterdam, Rijksmuseum, inv. RP-P-1961-717

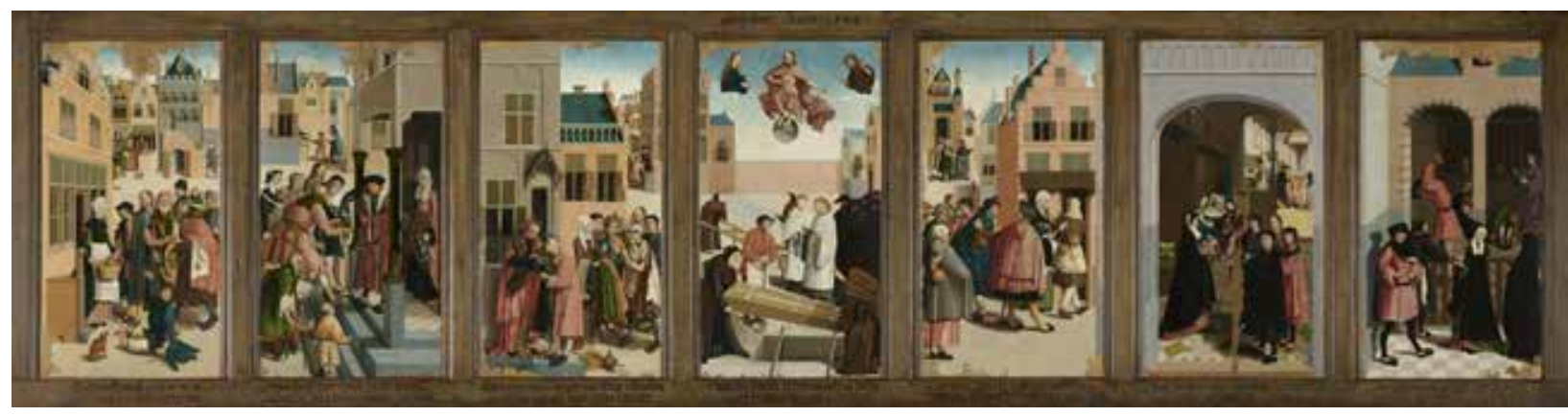

Fig. 12 Master of Alkmaar, Polyptych with the Seven Works of Charity, 1504, oil on panel, 119.1 x $469.5 \mathrm{~cm}$ (with frame). Amsterdam: Rijksmuseum, inv. SK-A-2815, purchased with the support of the Vereniging Rembrandt and the Commissie voor Fotoverkoop (artwork in the public domain)

Thus, Maria's closed eyes directly associate her depicted figure with an iconographic convention for blindness to, it seems, convey visual impairment. This point is leveraged by additional technical and visual evidence culled from the hofje's wings. In terms of the former, recent infrared reflectographic studies have revealed that Maria was represented with open eyes in the panel's underdrawing. ${ }^{34}$ The decision to represent her with closed eyes in the final painting must therefore have been deliberate. In terms of the latter, Maria's closed eyes contrast with the other four figures represented in the wings, whose eyes are not only open but also, it appears, focused: Saint James fixes his gaze on Jacob Van den Putte, Saint Margaret's is on Margaretha Svos, and the couple look down, at their clasped hands and open prayer books. Maria's visage 


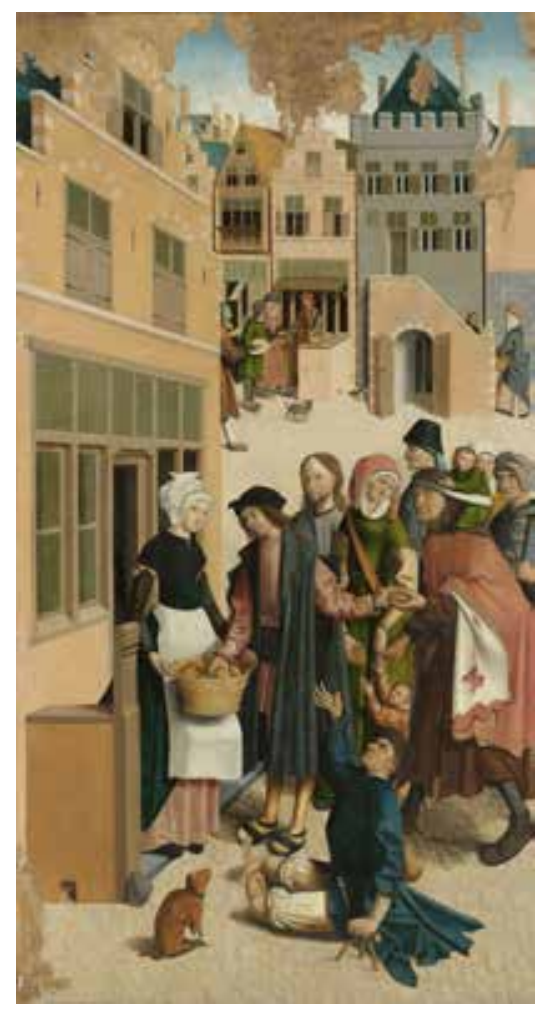

Fig. 13 Distributing Bread to the Blind and Needy (detail of fig. 12), oil on panel, $103.5 \mathrm{~cm} \_55$ cm. Amsterdam, Rijksmuseum, inv. SK-A-2815-1 (artwork in the public domain)

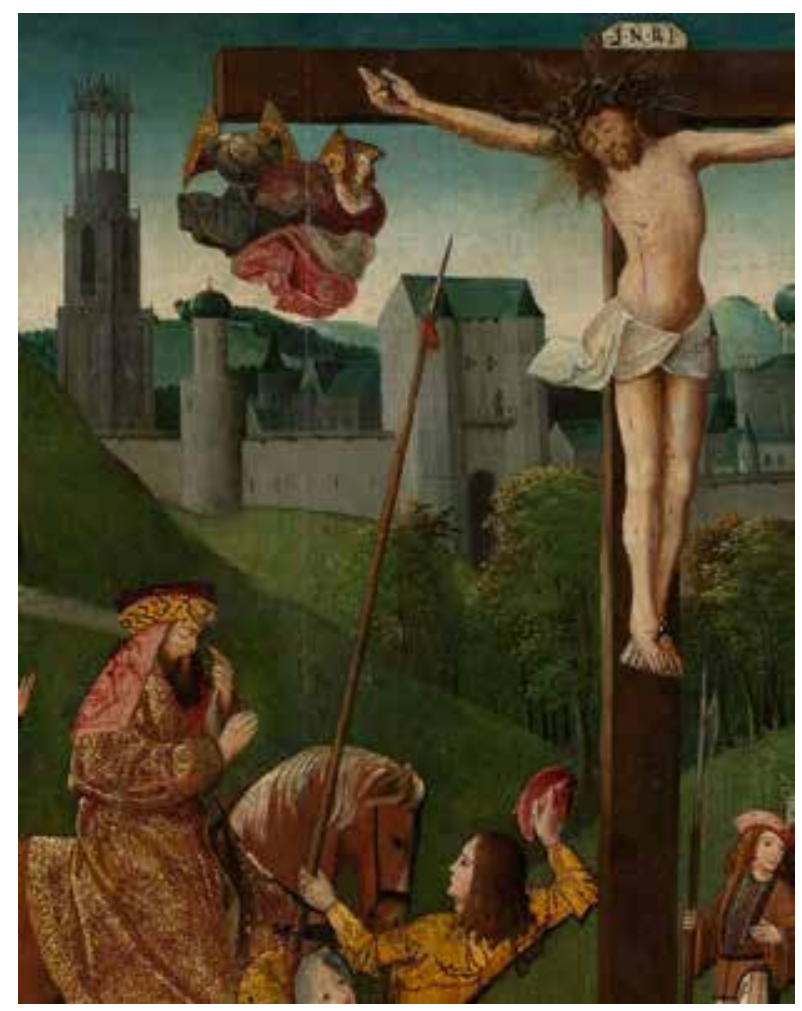

Fig. 14 Circle of Master of the Figdor Deposition, (Utrecht), Crucifixion (detail), 1505, oil on panel, $104.1 \mathrm{~cm} \_84.9 \mathrm{~cm}$. Amsterdam, Rijksmuseum, inv. SK-A-2212 (artwork in the public domain)

is further distinguished by the modulated rendering of her ocular orbits, as if they are swollen or malformed. Saint Margaret is rendered without such effect, and neither she nor Maria have the sagging flesh and crow's feet that convey middle-aged status for Margaretha Svos. Such distinctions demonstrate that the modulation of Maria's sockets cannot be dismissed as a clumsy handling of paint and brush by an inexperienced or unskilled artist. Clearly, the painter conceptualized her features, and those of her companions, with a real purpose. That these choices were made to convey sightlessness for Maria is suggested by yet another aspect of the hofje's imagery. The dragon in the shadows at the far right attends not to Saint Margaret, whom it represents as an attribute, but rather to Maria. ${ }^{35}$ It does so by means of sight: a singular luminous eyeball, defined by a large, bulbous shape, piercing black pupil, crimson iris, and gleaming white highlight, is trained on her face. This is quite unlike most other representations of Margaret's dragon, which either focus on her or the works' viewers. ${ }^{36}$ This unusual approach to the rendering of a saint's attribute must have been deliberate: it inventively attends to closed-eyed Maria's situation and to the hofje's larger emphasis on sight and seeing. In sum, the hofje's imagery blends convention with invention to prioritize vision and visual impairment.

15 The sightless state conveyed for Maria by her portrait helps to illuminate both her parents' motivations in commissioning the hofje and the reception of the work within the hospital context. It is important to acknowledge from the outset that the perspectives of the patrons and audiences of the work may not have aligned with one another: individual beholders of the hofje did not 
necessarily agree about its purpose or interpretation. ${ }^{37}$ This is all the more likely given that conflicting attitudes about disability and the disabled were circulating in various sociospiritual contexts. On the one hand, biblical scripture and related writings encouraged both empathy for the blind and the modeling of empathetic behavior toward those so afflicted. In the healing of a man blind from birth, described in John 9:2-3, Christ's disciples ask Jesus whether the man or his parents were to blame for his condition. Jesus replied that neither was culpable. Rather, the man was sightless so that "works of God might be made manifest within him." These "works" were made evident by the enactment of a miracle: Jesus healed the man's blindness. Images of this and other episodes in which Christ healed the sightless helped to advance a compassionate perspective toward the visually impaired. Compassion was crafted and expressed as well through a late-medieval spiritual economy that elevated the disabled while helping to ensure the salvation of the able-bodied. In her study on the rewriting of false miracles in England, Lindsey RowHeyveld concludes that late-medieval disabled persons held an "important role in a system of spiritual exchange in which the non-standard body served as a conduit for God; this exchange granted people with non-normative bodies a level of subjectivity and spiritual agency.... Able-bodied Christians gave [the disabled individual] alms ... and, in return, experienced an encounter with the divine facilitated by the disabled person." In the late-medieval charitable economy, then, people traded "salvation for alms, alms for salvation." Disability was "the crux on which this commerce balanced." 38

16 Images illustrated and encouraged an alms/redemption economy built around disability. One such work is the Master of Alkmaar's Polyptych with the Seven Works of Charity (see fig. 12), in which the disabled and the poor are depicted as recipients of alms. ${ }^{39}$ The first panel portrays a group of needy individuals, including the blind man already discussed, who seems pleased to accept a gift of bread from a layman and his wife (see fig. 13). The themes of the polyptych were inspired by Matthew 25:31-46, in which undertaking merciful deeds, such as distributing food to the indigent, is described as a pathway to salvation. An inscription beneath the first panel leaves no doubt as to the reciprocal nature of this system: "Be charitable to the poor / God shall once again have mercy on you (Deelt mildelick den armen / God zal u weder ontfarmen)." ${ }^{40}$ Perhaps even more to the point is that Christ appears behind the couple who distribute bread, drawing attention not to the act of charity but rather to the tangible space of the panel's viewers: his gaze meets theirs. He thereby implicates the beholders in an expectation of charity and, by extension, provides assurance that charitable actions will raise one's prospects for redemption. "Salvation for alms, alms for salvation" did not rest easily with everyone, however. As we will see, efforts were underway in some Netherlandish urban centers to decouple relief for the disabled from the expectation of redemptive almsgiving.

17 Sitting alongside the faith-driven ideologies of compassion and reciprocity toward the disabled were other ways of thinking that cast disabled people as sinful and therefore suspect. ${ }^{41}$ To take Maria's visual impairment as an example, suspicion was fueled by the deployment in texts and images of corporeal blindness as a metaphor for spiritual blindness. In this way of thinking, Maria's disability precluded her from reading and understanding the Word: hearing the scripture via recitation was not as potent as reading it oneself. Moreover, theologians such as Saint Augustine prioritized vision over the other senses in devotion. Augustine, in his conception of pathways to God, writes that sight required only light and not matter, which could dangerously 
arouse carnal desire (carnis appetitus): "So let us use for preference the evidence of the eyes; [sight] is the most excellent of the body's senses, and for all its difference in kind has the greatest affinity to mental vision (visio mentis)." ${ }^{2}$ "Sight controlled the other, more unruly, bodily senses and a sixth sense Augustine called the "eye of the mind" (oculus mentis) that kept the other senses in check to enable love of God. ${ }^{43}$ Such emphases necessarily disadvantaged the sightless by prioritizing vision to their exclusion. Relatedly, blindness precluded access to scriptural lessons presented in visual form and to images that could instruct viewers in other aspects of the faith, as advocated for the laity from the time of Gregory the Great. Some pictorial depictions of blindness helped to form and sustain biases against the blind by stigmatizing them, whether directly or by association. In personified figures of Synagogue, for instance, a blindfold and the blindness it produced signaled Judaism's errant rejection of Christian doctrine, ${ }^{44}$ and closedeyed Longinus tortured Christ. The disabled persons depicted in the Rohan Hours, produced in northern France in the 1420s, are cursed by Moses in one miniature and moralized negatively in another. ${ }^{45}$ In this moralizing of disabilities — what Ruth Mellinkoff has aptly termed "the bonding of disease and $\sin { }^{46}$ - afflicted persons were considered highly disadvantaged: their sinful states kept them from forging social relationships, contributing to the common good, and pursuing their own salvation.

\section{Sensory Redemption}

The Van den Putte/Svos hofje departs from other family triptychs, including the Moreel/ Valenderberch triptych, in its focus on a couple with only one of their children: as revealed in the Van den Putte/Svos testaments, the two had produced other children who do not appear in the wings. The work thus pertains first and foremost to the parent-child triad and not to the family as a whole. In light of Maria's apparent visual impairment and the negative conceptions of the blind and blindness that were circulating, the Besloten hofje seems intent on situating the spirituality of Jacob, Margaretha, and Maria favorably, to position all three as worthy of salvation; moreover, it asserts that Maria was deserving of profession at the hospital. This favorable presentation takes various forms. On a very basic level, all three supplicants are in prayer before the saints who appear in the garden, namely, Saints Ursula, Elizabeth of Hungary, and Catherine of Alexandria, which suggests a broad understanding of the various values they exemplified. For Maria these values included purity, charity, and wisdom, which were particularly emphasized in religious women's communities. Maria's brown habit and white wimple are those of a reformed hospital sister, which implies her acceptance by those women already professed at the hospital, her attire asserts her understanding of the specific spiritual values and charitable activities emphasized there, and her prayers imply devotional insight despite her impairment.

19 The sculptural nature of the garden plays into this conception. Exegeses and conventual prayer books demonstrate that the laity and perhaps especially religious women deployed not just the privileged sense of sight (and visualization) but their other senses as well, in various and sometimes blended ways, to become closer to Christ. ${ }^{47}$ In the case of the hofje, smell is invoked by the blossoms that laden the space; hearing by the parted lips of Saint Margaret that suggest speech or song and by the dragon's gaping jaws and fiery breath; taste by the grape clusters; and touch by the tactility of the garden's flora, fauna, sculptures, and relics. Perhaps Margaretha and Jacob chose to commission a sculptural work rather than a triptych with a painted central pan- 
el precisely because its tangibility better prioritized variety in sensory-based spirituality. One can even imagine Maria gently touching its sculptural elements to engage more directly with the holy objects and figures represented therein (the glass panes visible in some recent photographs of the hofje that would have precluded touch are later additions). Reindert Falkenburg has uncovered considerable textual evidence for a spiritually potent tactility and acts of touch in devotional tracts for the Netherlandish laity during this period, some aspects of which are illustrated in printed books. For instance, supplicants described as "souls" would pick fruit from trees or gather it from the ground, as in a woodcut of Christ and the Soul in the Garden of Gethsemane (fig. 15) from a tract called Die geestelicke boomgaert der vruchten daer die devote siel haer versadicht vanden vruchten der passien Christi (The spiritual orchard where the devout soul is satiated with the fruit of Christ's Passion), which was printed in seven editions between 1515 and $1546 .{ }^{48}$ In some manuscripts owned by religious women, supplicants are described as metaphorically reclining with their bridegroom Christ in a flower-strewn bed. Some women are described as undertaking interactive, materially based piety by dressing, caressing, and kissing sculptural representations of the Christ Child as expressions of veneration. A Christ Child, made ca. 1500 in Mechelen with a provenance of the Kloster zum Heiligen Kreuz in Rostock, Germany, is one such work (fig. 16); it was recently restored with a blue velvet and ermine mantle, alabaster rosary, and pearl-studded crown of the era and type that the sisters would have provided. ${ }^{49}$ In the context of Maria's disability, the materiality of the hofje makes a stronger case for tactile piety despite its visual pull than a work composed strictly of painted surfaces.

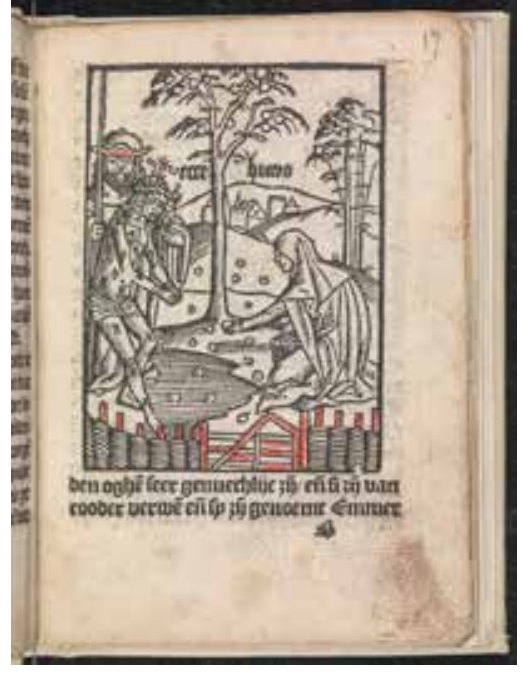

Fig. 15 Netherlandish, Christ and the Soul in the Garden of Gethsemane, from Die geestelicke boomgaert der vruchten daer die devote siel haer versadicht vanden vruchten der passien Christi (The spiritual fruit garden where the devout soul is satiated with the fruit of (hrist's Passion), woodcut from an edition printed in Utrecht by Jan Bernsten, 1521. The Hague, Koninklijke Bibliotheek, inv. $150 \mathrm{G} 44$, fol. 17r

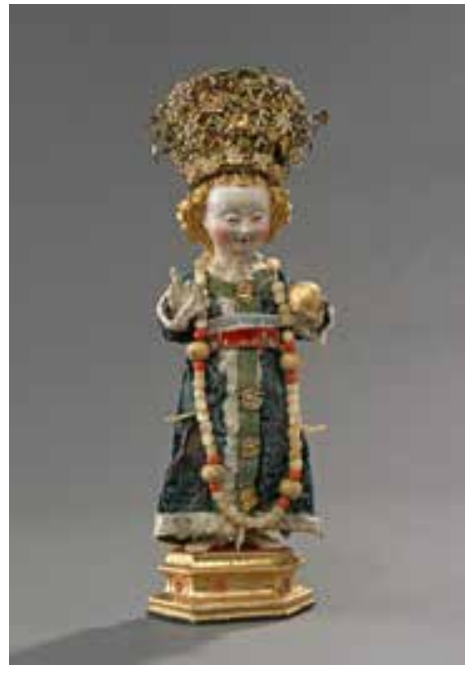

Fig. 16 Mechelen, Christ Child, ca. 1500, polychromed wood, gold, alabaster, velvet, ermine, pearls, and other materials, $h$. $30.5 \mathrm{~cm}$. Schwerin, Staatliches Museum, Schloss Güstrow. (c) Staatliches Museum Schwerin, photo: Hugo Maertens (artwork in the public domain)

20 Other aspects of the hofje help to illuminate more deeply the relationship between Maria's problematic body and the hope for her salvation. One is her hands (see fig. 5), which are held together in prayer in conventional fashion. The dorsum of her left hand is the most prevalent feature. The smallest finger and right edge of the left-hand palm peek out from beneath it at the 
lower edge, and the tip of the thumb of the right hand is also partially depicted. Unusually, Maria's hands are rendered in larger scale and with longer and broader digits than would be expected in relation to the scale of her figure. Her hands are nearly as large as her head, and they are markedly larger than the hands of her parents despite the ampler scale of their figures. In fact, Maria's hands are comparable in size and even slightly broader than Saint Margaret's, whose figure is comparatively much larger, rendered in hieratic scale, to emphasize her import: her hands are proportionate to her own frame. In this presentation, which seems as carefully planned as the rendering of Maria's ocular orbits in contrast to those of the other figures, Maria's hands are relationally emphasized. Such emphasis may have signaled the practice of devotion-by-feel discussed above. It also connects Maria to trends in spiritual meditation that activated piety through the hands. These bodily features were put to meditative and mnemonic use in prayer through the association of its individual elements - the palm, digits, joints, and nails-with specific devotional exercises. ${ }^{50}$ For instance, Latin inscriptions in a woodcut of 1466 depicting the palm-side of the left hand (fig. 17) identify the thumb - the privileged digit—as symbolizing God's will. The four fingers represent four stages of contemplation, namely, examination, repentance, confession, and satisfaction. The joints are identified as steps a devotee would undertake in each meditative stage. A similar image, a Chiropsalterium (handpsalter) (fig. 18), was developed by the Augustinian canon and reformer Jan Mombaer for his Rosetum exercitiorum spiritualium et sacrarum meditationum (Rosary of spiritual exercises and sacred meditations) and printed at Zwolle in 1494. Here again, the fingers and joints are inscribed with meditative cues. The inscriptions above and below the image, which are culled from the Psalms and other books of the Bible, invoke and encourage sensory-driven devotion by emphasizing hearing, through references to music and those who produce it. "Praise him with the sound of the trumpet, psaltery, and harp," the text urges; the reader should rejoice in "embracing musicians of all kinds in the Holy Spirit." ${ }_{51}$ Maria's body may not have been as abled as the bodies of other supplicants, but her out-scaled hands align her viably with a spiritual memory practice that privileges a type of piety she could in fact enact.

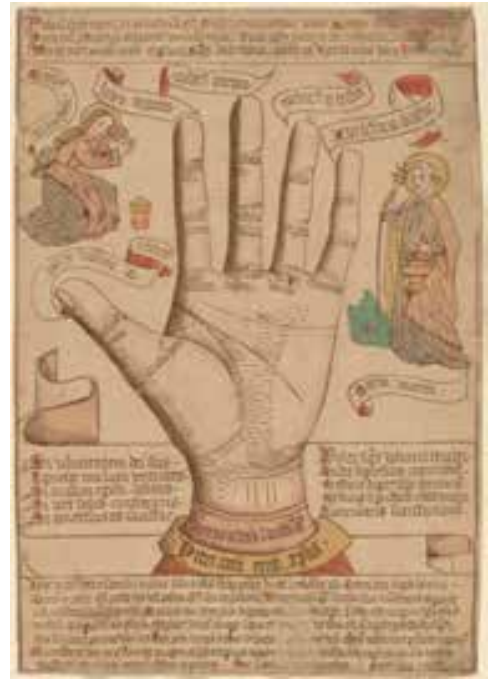

Fig. 17 Netherlandish (?), The Hand as the Mirror of Salvation, 1466, hand-colored woodcut, $39.138 .9 \times 2726.8 \mathrm{~cm}$. Washington, D.C., National Gallery of Art, Rosenwald Collection, inv. 1943.3.639 (artwork in the public domain)

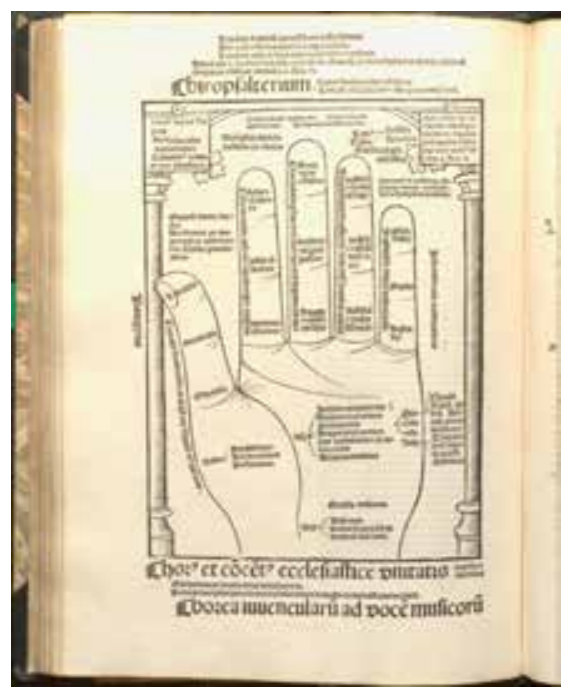

Fig. 18 Jan Mombaer, Chiropsalterium (Handpsalter), from Rosetum exercitiorum spiritualium et sacrarum meditationum (Rosary of spiritual exercises and sacred meditations) (Zwolle, 1510), woodcut, $19.7 \times 14.5 \mathrm{~cm}$. Washington, D.C., Library of Congress, Music Division, ML171.M19 Case, n.p. [AaL2] (artwork in the public domain) 
The enclosed garden helps to counter another enduring negative association with blindness and the blind, namely, sexual misbehavior. ${ }^{52}$ Such ideas were inspired by two primary contexts about sexual acts that powerfully condemned the visually impaired. The first was in the form of narratives revived from antiquity, which grew in popularity among the laity in the fifteenth century and that were expressed in textual and pictorial form. An example is the story of Oedipus and Jocasta: Oedipus gouged out his own eyes for marrying and having intercourse with his mother, Jocasta, from whom he had been separated as an infant and who he did not recognize as an adult. This episode circulated widely in Boccaccio's On Famous Women of ca. 1360, printed in Ulm in 1473, Louvain in 1487, Strasbourg in 1488, and in Antwerp in 1525 as Poeet ende Philosophe, bescrivende van den doorluchtighen, glorioesten ende edelsten vrouwen. The printers relied on the same or very similar sets of woodblocks to illustrate their volumes. ${ }^{53} \mathrm{~A}$ woodcut from the 1473 edition (fig. 19) depicts Oedipus's abandonment as a baby in the left foreground; on the right, the adult Oedipus blinds himself while Jocasta commits suicide as self-inflicted punishments for their incest (although neither was aware of the sinful nature of their contact until later). The second context was Judeo-Christian critiques of sexual behavior and activities, which assigned blindness as a punishment for various transgressions of the kind. In Genesis 19:1-11, for example, sodomites are struck down by blindness to keep them from committing a carnal act declared sinful by Lot.

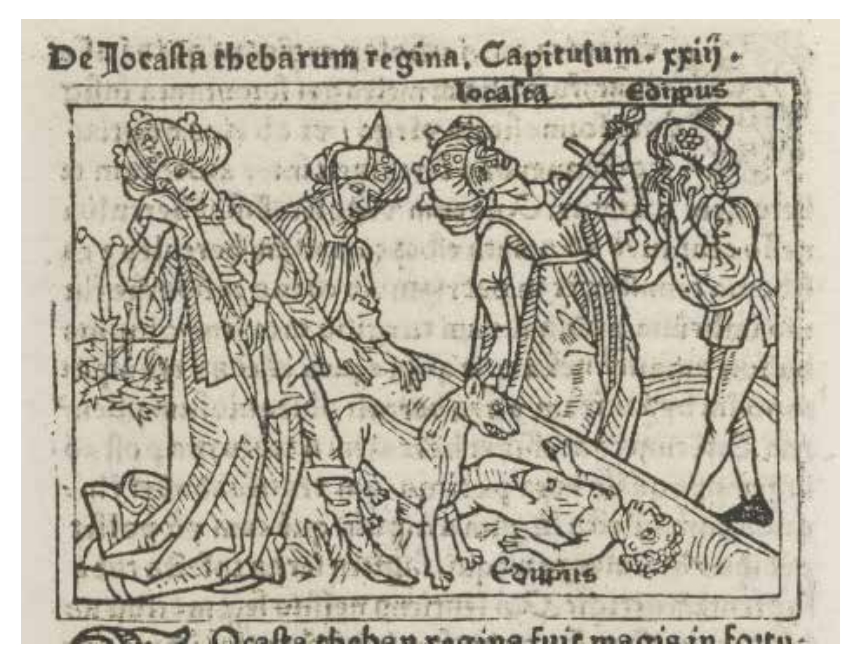

Fig. 19 German, Jocasta and Oedipus, from Giovanni Boccaccio, De mulieribus claris, (Ulm: Johann Zainer, 1473), woodcut, chap. 23. Washington, D.C., Library of Congress, Rosenwald Collection, Incun. 1473.B7, fol. 25v (artwork in the public domain)

In contrast to these negative perspectives, the enclosed garden of the hofje carried associations of sexual restraint. The passage in the Song of Songs that eventually came to signal the Virgin Mary's purity - "a garden enclosed, sister my bride / a garden enclosed, a fountain sealed"-ultimately inspired numerous depictions of Mary in walled gardens, such that by the fifteenth century the theme was pervasive in northern European representation. Examples are found in painting, drawing, sculpture, manuscripts, prints, and the fiber arts. In an ivory carving made in the Netherlands at the close of the fifteenth century, Mary is shown in an enclosed garden surrounded by symbols of her purity (fig. 20). ${ }^{54}$ Women who professed in religious communities, as Maria had, took a vow of virginity (or chastity if they had already been married). This commitment is addressed in the reform statutes from the Onze-Lieve-Vrouwegasthuis, in part by imposing a modified enclosure for the hospital sisters, which kept contact to a minimum while allowing access to the infirm to administer care. ${ }^{55}$ The connection between enclosed spaces and virginity is made explicit in a fifteenth-century devotional text that Kathryn Rudy calls the Spiritual Bedroom, which in all likelihood belonged to sisters at 
the Augustinian hospital at Geel, reformed by the Mechelen sisters in $1552 .{ }^{56}$ The Spiritual Bedroom instructs its reader to build in her heart a bridal chamber in which she would receive Christ, her beloved. The sister is to paint the walls green and adorn the edges with painted blossoms to construct an enclosed garden. The green of the walls is described as virginal, thereby connecting the garden directly to sexual propriety via color. ${ }^{57}$ Once the room was furnished, Christ would lay with the supplicant and their flesh would metaphorically conjoin in a virtuous expression of conjugal fulfillment. The green foliage in the hofje, albeit faded with time, may have carried similar symbolic associations for its patrons and audiences thus claiming for Maria its positive values.

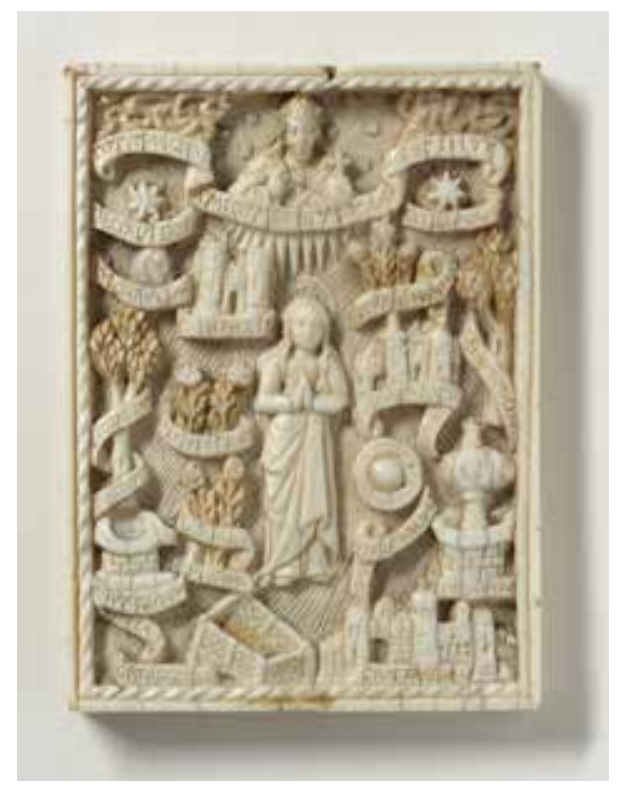

Fig. 20 North Netherlands or Flanders, Immaculate Virgin, ca. 1480-1500, ivory with traces of polychrome, h. $11.3 \mathrm{~cm}$. Amsterdam, Rijksmuseum, inv. BK-2008-69, purchased with the support of the Frits en Phine Verhaaff Fonds/Rijksmuseum Fonds (artwork in the public domain)

Medieval exegeses and medical treatises attributed healing properties to tastes and fragrances, which in the hofje connect Maria to notions of bodily and spiritual healing. Influenced by the Galenic conception of the six non-naturals, the traditional medieval health regimen (regimen sanitatis) encouraged the consumption of healthy foods and the inhalation of sweet fragrances to promote sound health, prevent disease, and encourage healing. ${ }^{58}$ Such ideas received attention as well in the highly influential Isagoge (Introduction to medicine) written by the Arabic physician Hunayn Ibn Ishaq al-'Ibadi in the ninth century, which assigned healing properties to floral aromas; the text was translated at the Benedictine monastery of Monte Cassino near Rome in the eleventh century and disseminated widely in the Christian world thereafter. ${ }^{59}$ The Isagoge and the writings it influenced identified ambient air or smell as the most important of the senses, for it more than any other sense was thought to preserve life. Pleasing scents and tastes could not only heal the body but also the soul. Fragrances in the prelapsarian Garden of Eden were considered by medieval authors to enable just this. ${ }^{60}$ Healing the spirit by scent was taken up in certain fifteenth- and sixteenth-century devotional tracts, including Die geestelicke boomgaert. ${ }^{61}$ In one passage, Christ presents the soul with a red rose, to "pluck if you love me as I have loved." He directs the soul to "always bear in your heart the odor of the red rose for my sake as I have suffered for you." The fragrance of the rose binds the soul of the reader to Christ, to strengthen the memory of his sacrifice for human salvation and, ultimately, to lead the devotee to redemption. Such connections were made visually evident in woodcuts, such as Christ and the Soul in the Garden of Gethsemane (see fig. 15); in this Holy Land image, the figures are set in an 
enclosed garden, thereby linking the themes of the text to those of the Besloten hofjes. Inhaling sweet scents in walled gardens was in fact considered a more effective way to promote health and healing than doing so in open gardens, for the barriers retained and intensified the fragrances of the plantings therein. ${ }^{62}$

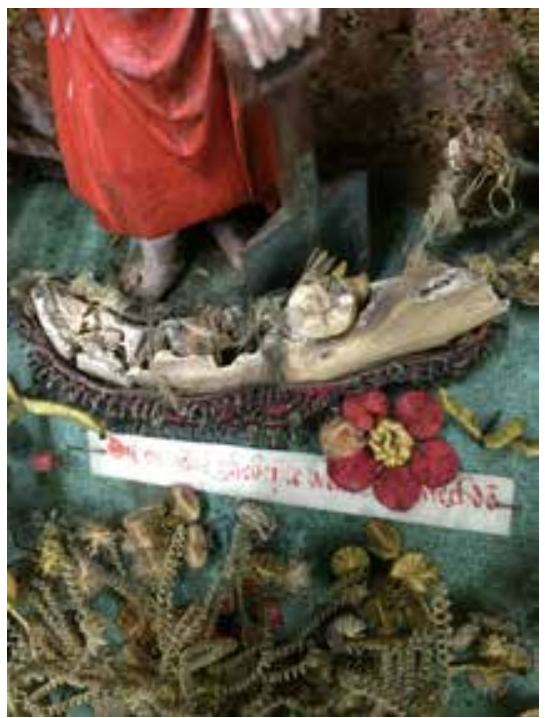

Fig. 21 Jawbone relic labeled, "This is from the bones of the 11,000 virgins (Dit es ghebe[e]nte vande[n] xim mechde[n])," (detail of fig. 1)

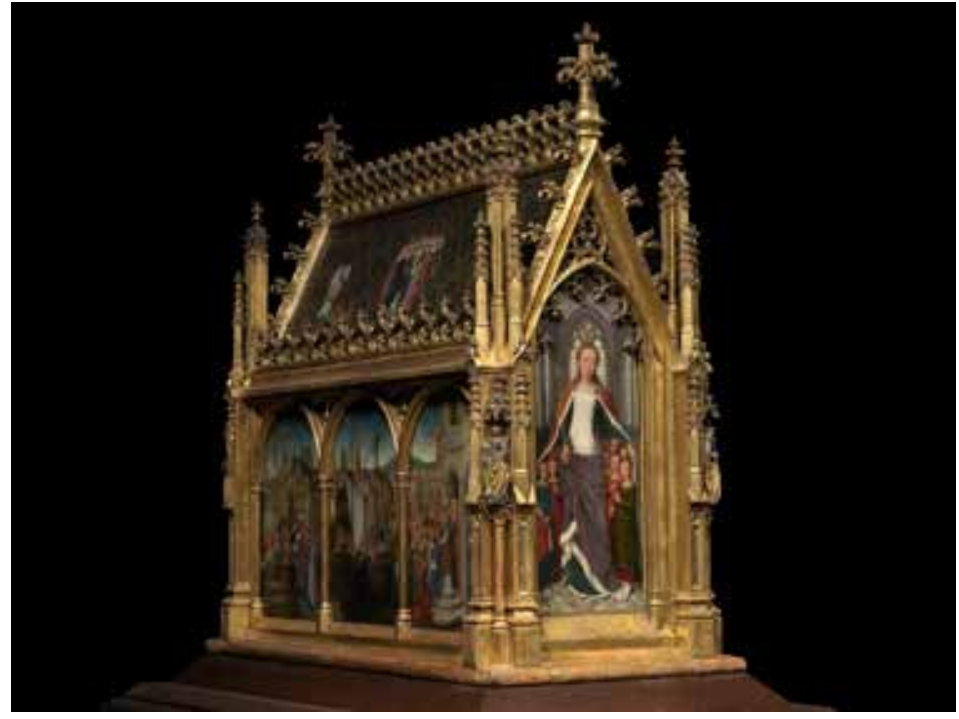

Fig. 22 Hans Memling, Saint Ursula Shrine, 1489, oil and gilt on wood, $9991.5 \times 91.599 .2$ x $41.5 \mathrm{~cm}$. Bruges, St. John's Hospital, @ Lukas - Art in Flanders VZW, photo Hugo Maertens, https://creativecommons.org/licenses/by-nc-nd/4.0/legalcode (artwork in the public domain)

24 It was not only the blossoms and their implied fragrances in the hofje that held restorative possibilities, however, but also the relics. Over three dozen relics are included in the garden, more than any other hofje in the hospital's possession (albeit some original components of the works may have been removed over time) ${ }^{63}$ As with other relics, these objects were assigned curative possibilities for physical and moral defects, if not in the material world then in the afterlife. ${ }^{64}$ Cataloging the relics in the hofje through their authentiques, paper banderoles with inscriptions that ascribe them to saints and thus declare their authenticity, reveals that some pertain to particular saints, including Saints Jerome, Dorothy, Bartholomew, and Barbara ${ }^{65}$ Some authentiques attribute their relics to the Holy Land, and seven identify relics of the legendary 11,000 virgin martyrs (see fig. 2 and fig. 21), who accompanied Saint Ursula on a pilgrimage to Rome and who were put to death with her in Cologne on the return journey. The legend received widespread attention, in part through Jacobus de Voragine's Legenda aurea of ca. 1260 and through many images that convey the narrative or present the figures devotionally. In terms of the latter, Ursula's role as a protector - she is portrayed in the hofje shielding four of her virgin companions - was invoked on behalf of the caretakers and the infirm. Images of Saint Ursula were present in some other hospitals, suggesting that this imagery played a role in promoting these connections more broadly. For example, administrators at the Sint-Janshospitaal in Bruges commissioned a shrine of Saint Ursula to hold relics in the institution's possession (fig. 22). Ursula is shown on one end safeguarding her virgin companions under her cloak, while two hospital sisters appear with the Virgin Mary and the Christ Child on the other. The reliquary, housed in 
the institution's chapel, would have been visible to most patients from their sickbeds; ${ }^{66}$ prayers recited in the presence of the relics would have been considered especially potent in their healing and hope for salvation. Tales of the miraculous appearance of the 11,000 virgins to the dying, and their intercessory role in the process of death and salvation, were also prevalent: Voragine's Legenda aurea connects the virgins to the illness, death, and reception of a monk in heaven:

A certain religious who had great devotion for these virgins was gravely ill, and one day saw a most beautiful virgin appearing to him and asking if he recognized her. ... [S] he said, "I am one of the virgins for whom you have such devotion. We want you to be rewarded for this, and so, if for love of us and in our honor you will recite the Lord's Prayer eleven thousand times, you will have us to protect and console you at the hour of your death." She disappeared, and the monk fulfilled the condition as fast as he could. ... [A] little later . . he had migrated to the Lord. ${ }^{67}$

Themes of restoration and redemption of the ill pertain in the hofje in another way as well, through the wax medallion of the resurrected Christ that appears at the upper center of the garden (see fig. 10). The medallion draws Maria into the proximity of the restored body of the Savior, just as she is also drawn into proximity to the relics in the hofje's sanctified terrain. In linking her to a representation of the savior's resurrected flesh, the same status is claimed for her body and soul in the next world. In sum, the hofje presents Maria as a spiritually abled if not a visually abled member of the hospital community, one who is deserving of profession and redemption.

\section{Parental Anxieties and the Audiences of the Hofje}

The hofje claims salvation not only for Maria but also for her mother and father in their positions as her charitable providers. Doing so may have seemed crucial, since parents such as Margaretha Svos and Jacob Van den Putte, who produced children disabled from birth or who became so later, were looked upon unfavorably by some: their children's afflictions were considered punishment for their own sinful behavior. This perspective was expressed in John 9:2, discussed above, in which Jesus heals a man blind from birth. This miraculous episode may have aroused sympathy for the disabled as we have seen, but the question of whose sin was to blame for the man's disability, his or his parents', points to a blame-game in which parents were deemed morally suspect because of (and along with) their stricken children.

In the hofje, by contrast, Margaretha and Jacob appear as ideal supplicants and ideal parents, as generous providers for their daughter. Their presence facilitates pictorially and symbolically Maria's access to the sanctified, healing garden (even if Maria could not see that herself), as though they and especially Margaretha are interceding for her as the immediate conduits for their daughter's spiritual well-being. The figures of Elizabeth of Hungary, with a disabled man at her feet-she was known to bathe lepers-and Ursula protecting her virgin companions, reinforce notions of charity and caregiving. Certainly it was Margaretha and Jacob who arranged a place for Maria at the hospital, an institution that by its very nature would cultivate her piety. The prayers of nuns, furthermore, were considered especially efficacious-as were the healing properties of rosaries and the coral from which Margaretha's beads were made ${ }^{68}$ - perhaps even more so those of hospital sisters, who at this time were among the most appreciated agents of physical and spir- 
itual health for the infirm. ${ }^{69}$ The Besloten hofje thus conveys a charitable spiritual provision for Maria on the part of her parents, as a visual parallel of sorts to the couple's temporal charitable provision for her in their will. The hofje was perhaps also intended by Maria's parents as a devotional aid-Maria could activate her piety through the sense of touch as described previously-such that it made a means of sensory devotion viable for her despite her impairment. Such actions represent the couple's concern for their disadvantaged child. They are also consistent with a broader commitment to the benevolent activities exemplified in Jacob's role as "master" of the Confraternity of the Holy Spirit at Hanswijk, which provided relief for those in need.

Jacob and Margaretha may have considered themselves especially pressured to provide for their daughter, as deeper anxieties about the disabled, including the blind, were surfacing in mainstream thought during this period. To be specific, the major urban centers of the Low Countries were debating ways in which health care for the needy was administered and regulated. The aim was to reduce mendicancy, which was increasingly seen as a public nuisance. Proponents of this cause proposed retaining the urban monastic infirmaries that traditionally administered care for the ill and destitute, so that the Christian principle of love for one's neighbor would be retained..$^{70}$ But these institutions would operate under stronger surveillance and greater intervention by the city governments. A formal strategy of this kind was proposed by the humanist author Juan Luis Vives in his treatise, De subventione pauperum sive de humanis necessitatibus (On assistance to the poor or, on human necessities), which was commissioned by the city of Bruges and published in January of $1526 .^{71}$ De subventione pauperum was focused primarily on the poor, but it also addressed issues pertaining specifically to the sick and disabled in hospitals, where the infirm, orphans, and "the mentally ill are kept and [also] the blind." ${ }^{2}$ Vives makes a case for scrutinizing the conditions of institutionalized persons with the purpose of putting to work those who were able. Of the sightless he writes:

I should not allow the blind to sit around or wander about idly. There are many things in which they could be employed: some are good at letters, let them study (in some cases we have seen considerable advancement in learning); others are gifted for music, let them sing, strike at the lyre, blow on the flute; some can turn the grain-mills, others work at the presses; others can blow the bellows in the forges. We know that the blind can make little boxes, chests, baskets, and cages; blind women spin and wind yard. Let them not wish to be idle or avoid work; they shall easily find things with which to occupy themselves. Laziness and sluggishness are the reason why they say they cannot do anything, not a physical defect. ${ }^{73}$

Historians are currently re-evaluating the social, religious, and economic pressures that brought about the revision to humanitarian efforts on behalf of the destitute and infirm. ${ }^{74}$ Of importance here is that Vives and at least some of his contemporaries believed that the visually impaired were resistant to undertaking productive work that contributed to the common good. Such thinking no doubt helped to marginalize disabled individuals such as Maria Van den Putte even more deeply. At the same time, however, her situation was better than those of impaired persons whose families did not have the means or desire to care for them. Jacob and Margaretha were not only willing and able to provide for their daughter financially, as evidenced by their will, but they 
also commissioned and arranged for the presence of an expensive devotional work packed with relics of high value to the community that had accepted her as one of their own.

Margaretha and Jacob also may have hoped that the hofje would mediate socially with the sisters, whom they certainly understood as viewers of the work, on behalf of Maria's physical and spiritual well-being. Surely the couple trusted them to provide exemplary spiritual and physical care for their daughter or they would not have chosen this particular community as her perpetual place of residence. Its recent history did not necessarily support that perspective, however. Prior to the reforms the sisters had been accused by the bishop of Cambrai of significant lapses in the hospital's commitment to the infirm. The preface to the reform statutes, written by the Mechelen-born reformer Jan Standonck, reports that in a visitation made by the bishop in 1500, "various deficiencies of all kinds [had been found in] the women and nuns of the aforementioned hospital, in their religion, rules, and the three vows they professed [poverty, chastity, and obedience], and also in the care, service, and protection of the sick." ${ }^{75}$ Subsequent visitations revealed that "the aforementioned women and nuns failed profoundly in compliance, in maintaining and following the way of life conveyed in the rules," despite the fact that they had "promised to do this to the best of their ability." "But in our times [ca. 1509], [the sisters] not only despised, forgot, and abandoned all the rules and ordinances, but also their spirituality and discipline in the aforementioned hospital, and they performed worse in the service of the sick and poor than before. All this is a heavy burden and a danger to their souls and a great disadvantage and damage to the aforementioned hospital and to the detriment of the poor and sick." ${ }^{77}$ Under these deteriorating conditions, Jacob de Croÿ installed at Mechelen two sisters from the Augustinian hospital of Sint-Jans near Brussels to enforce the reforms. They were Cornelia Andries and Sozijne Van Coolene, whose portraits appear in the wings of a Crucifixion hofje also in the Mechelen hospital's possession, which is discussed below. ${ }^{78}$ If Margaretha and Jacob commissioned the hofje between 1513 and 1524 as proposed, they did so relatively soon after the institution of the reforms, of which they likely were aware as neighbors to the hospital. The hofje's portraits kept Maria, Margaretha, and Jacob under the sisters' eyes and in their minds, reminding them about their commitment to their disabled sister and her family. ${ }^{79}$

31 Margaretha and Jacob may also have intended the hofje as a gesture of gratitude to the community for accepting Maria as a professed member. The sisters in fact made a certain sacrifice by doing so, for Maria was unable to contribute to the most arduous and unpleasant aspect of daily life at the community, namely, the work of the infirmary. The reform statutes reveal something of the extent of this burden. The community comprised sixteen sisters who were charged with carrying out the work of the infirmary on their own, without hiring assistants; novitiates who could or would not pull their weight were to be expelled before profession. On the other hand, taking in Maria was a means by which the sisters could demonstrate their commitment to the reformed hospital's mission. It would embed them into a spiritual economy that diminished the "danger to their souls" identified earlier by Jan Standonck as a consequence of the community's prior negligence. The hofje may have encouraged a communal devotional practice of sorts, with the sisters engaging with Maria (or on their own) in a tactile-driven practice of touching the garden. The garden was indeed potentially transformative, as Kathryn Rudy describes: "It is a vehicle that transforms the hospital sister's surroundings, full of the dead and dying, the suppurating 
and putrescent, to the world of the idealized saint's body, whose bones are preserved among the relics from the Holy Land and do not decompose." ${ }^{80}$ The holy matter of the Van den Putte/ Svos hofje promises rejuvenation not only to its patrons and their daughter but to her caretakers as well.

\section{Rethinking Production}

Having now identified Jacob Van den Putte and Margaretha Svos as likely responsible for commissioning the hofje - they are represented in positions and attitudes normally reserved for patrons-certain enduring perceptions about the work's origins and manufacture must be revised. As discussed above, the sisters of the Onze-Lieve-Vrouwegasthuis have been credited with producing the hofjes in their possession, including the Van den Putte/Svos example. In this model, the sisters made the botanical elements; assembled and installed them in the wood cabinets with prefabricated sculptures and relics; and commissioned the painted shutters from local artists, whose identities remain unknown. Aspects of this proposal make considerable sense at first glance, for it is certain that some Netherlandish nuns in this period produced handwork for and assembled hofjes. For example, Margaret of Austria commissioned a small garden (jardinet) made of "flowers of silk and other minutia" from the convent of Galilea in Ghent, a community of contemplative Windesheim canonesses. Margaret dispatched her court illuminator, Gerard Horenbout, to Galilea to supervise the lengthy project-he was there for twenty days-probably to ensure the hofje's quality, as Dagmar Eichberger has proposed. ${ }^{81}$

33 Yet it is no longer possible to accept this standard model of production for the Van den Putte/ Svos hofje. Certainly it was Jacob and Margaretha, not the sisters of the Onze-Lieve-Vrouwegasthuis, who commissioned the shutters, with imagery that so clearly conceptualizes the hofje as a family triptych. The imagery pertains deeply, precisely, and personally to the couple and their daughter, not directly to other sisters at the hospital or to the community at large. It is also unlikely in this specific situation that the sisters produced the hand-wrought elements of the hofje and assembled the garden: it would have made little if any sense for Jacob and Margaretha to have asked them to do so. Indeed, a collaborative effort seems out of the question in the case of this family triptych, with its very clear emphasis on a couple and their daughter. Furthermore, thinking practically, it seems unlikely that the hospital sisters could have accomplished such arduous work while also caring for the infirm, a round-the-clock occupation. Although the Mechelen statutes of reform advise the sisters to engage in sewing and spinning in any spare time that happened to arise, ${ }^{82}$ it is unlikely that these activities reached past the basic sewing and repairs that were necessary in a hospital context. The situation was comparatively very different from that of Galilea in Ghent, a contemplative convent where conditions better enabled activities of the kind.

In fact, a survey of the Mechelen hospital's financial registers has not revealed the purchase of silk, thread, wire, or beads (the materials from which the hofje's flora and fauna are made), nor do they mention the acquisition of relics or sculptures. ${ }^{83}$ It may not have been necessary to record such things, however. The relics, for instance, could have been given to the community or acquired from the hospital's patients, ${ }^{84}$ especially since the sisters were permitted to retain possessions left at the hospital by the deceased. ${ }^{85}$ Yet the registers do reveal that the sisters did not make, 
but rather bought, in 1519, a "crown" ("croone[n]") made of wax and flowers that hung in their refectory. ${ }^{86}$ The express purchase of the "crown" strongly suggests that the sisters procured handworked items externally. This is not to say, however, that they avoided manipulating the hofjes in their possession. In the case of the Van den Putte/Svos example, they may have added some of the relics that appear along the inner lateral sides of the cabinets. They also may have been the ones to remove wings that once adorned one of three Crucifixion-themed hofjes at the hospital (fig. 23 $)^{87}$ : perhaps the work did not originate with the patronage of the community or its associates, and therefore the pictorial content of the shutters, which may have included portraits, did not suit them.

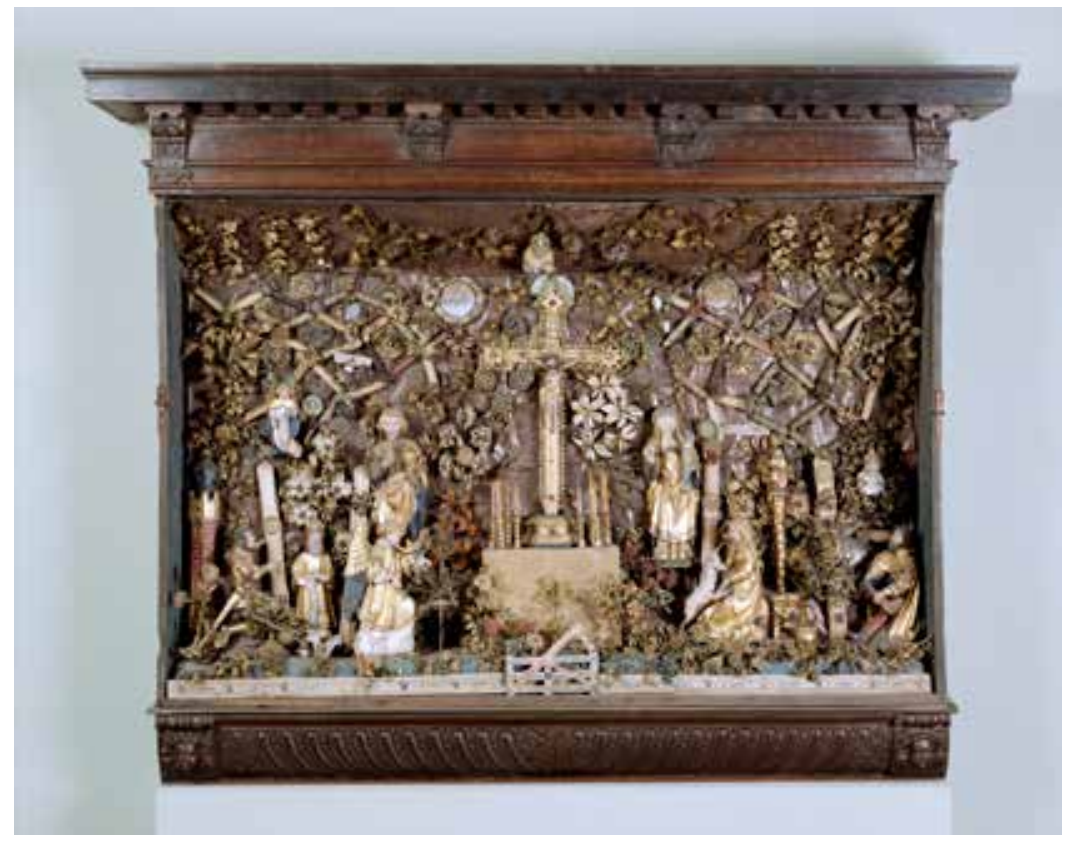

Fig. 23 Mechelen (?), Crucifixion Hofje, ca. 1510-30, polychromed wood, silk, paper, bone, wire, paint, and other materials in a wood case, $158.5 \times 139 \times 33 \mathrm{~cm}$. Musea \& Erfgoed Mechelen, inv. BH/1, Collectie Gasthuiszusters, Onze-Lieve-Vrouw Waver, on long-term loan from the Augustinian Sisters of Mechelen, (c) KIK-IRPA, Brussels, www.kikirpa.be, cliché KN008407, photo: Jean-Luc Elias (artwork in the public domain).

It seems evident, then, that the sisters participated neither as patrons nor makers in the production of the Van den Putte/Svos hofje. This new perspective unravels certain assumptions about the manufacture of other hofjes at the Onze-Lieve-Vrouwegasthuis. For example, the fruit and flower elements of the Van den Putte/Svos hofje, and the arrangements of these adornments in trellises along the back wall of the cabinet, are so alike in manufacture and composition to two other hofjes from the hospital that all three must have been made at the same workshop if not by the same sets of hands. The similar works are, first, a reform-related Crucifixion hofje(fig. 24) and, second, a hofje with Sint-Anna-ten-drieën ("Saint Anne in threes," a reference to the three generations represented by the figures of Anne, Mary, and the Christ Child) (fig. 25), both of which are discussed further below. If the sisters did not produce the handwork for the Van den Putte/Svos hofje, then neither did they create it for the Crucifixion and Saint Anne hofjes.

If these three hofjes were not products of the Onze-Lieve-Vrouwegasthuis, it seems likely that they were manufactured in professional workshops, perhaps with nuns at one or more of the contemplative convents in the city contributing the topographical adornments of the gardens. This premise corresponds with Appuhn and Krohm's proposal, discussed above, that the extraordinary technical skill demonstrated by these elements points to such circumstances. 

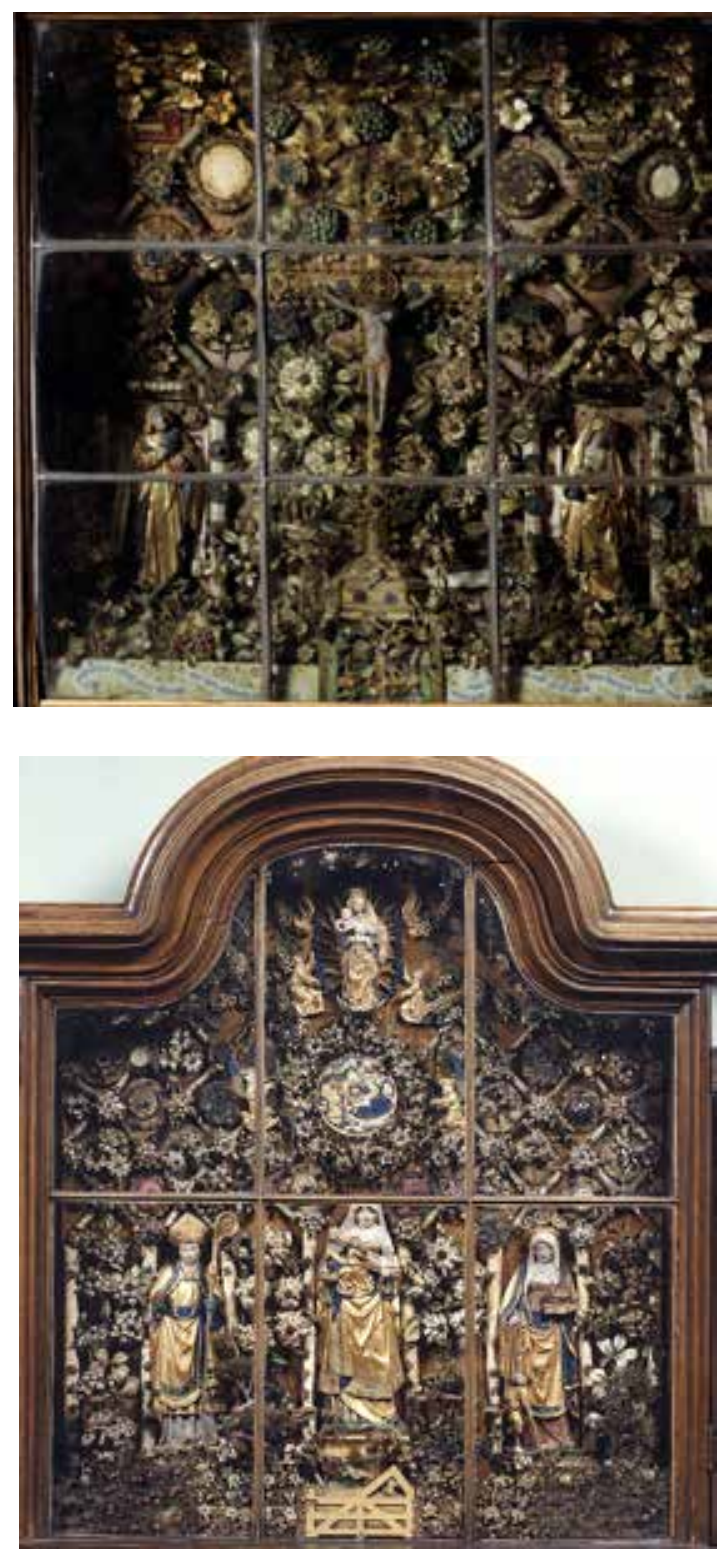

Fig. 24 Mechelen, Crucifixion Hofje (central cabinet), ca. 1525-28, polychromed wood, silk, paper, bone, wire, paint, and other materials in a wood case, $109 \times 89.7 \times 19.5 \mathrm{~cm}$. Musea \& Erfgoed Mechelen, inv. BH/3, Collectie Gasthuiszusters, Onze-Lieve-Vrouw Waver, on long-term loan from the Augustinian Sisters of Mechelen, (C) KIK-IRPA, Brussels, www.kikirpa.be, cliché KN008410, photo: Jean-Luc Elias (artwork in the public domain)
Fig. 25 Mechelen, Besloten Hofje with Saint Anne, the Virgin Mary, and the Christ Child (Sint-Anna-ten-drieën), Saint Augustine, and Saint Elisabeth (center cabinet), 1529 (?), polychromed wood, silk, paper, bone, wax, wire, and other materials in a wood case, $150 \times 120 \times 38$ $\mathrm{cm}$. Musea \& Erfgoed Mechelen, inv. BH/6, Collectie Gasthuiszusters, Onze-Lieve-Vrouw Waver, on long-term loan from the Augustinian Sisters of Mechelen, ( ) KIK-IRPA, Brussels, www.kikirpa.be, cliché KN008403, photo: Jean-Luc Elias (artwork in the public domain)

Yet this hypothesis may soon be revised. The Mechelen hofjes are undergoing restoration in preparation for an exhibition titled In Search of Utopia, organized by the Illuminaire Center for the Study of Medieval Art at the Katholieke Universiteit Leuven and the Museum-M Leuven. ${ }^{88}$ It is possible that the restoration process will uncover new material evidence, and that additional archival work will reveal heretofore undiscovered written records, which will compel the revision of my argument. It seems safe to say, though, that at least two and probably three of the hofjes were made in Mechelen. My preliminary examination of the hofjes' cabinets in 2013 revealed the stamps of professional carpenters from Mechelen on the lateral exterior sides of the reform-related Crucifixion and Sint-Anna-ten-drieën hofjes ${ }^{89}$; the stamps take the form of the Mechelen drie palen (three poles), a motif drawn from the city's heraldry (fig. 26 left, fig. 26 right), ${ }^{90}$ which indicate that the cabinets were made in the city. Together with the works' Mechelen provenance, the stamps strongly suggest that the two hofjes were locally made. If so, then the Van den Putte/Svos hofje was as well, for its botanical elements and trellislike forms 
echo those in these works.

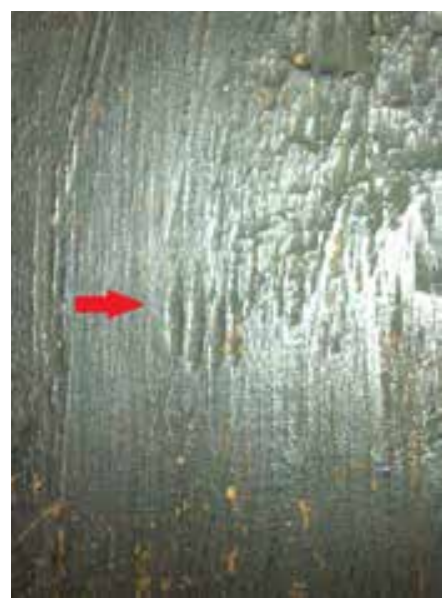

Fig. 26-left "Drie palen" stamps from central cabinets of Besloten Hofjes. Left: Mechelen Musea \& Erfgoed, BH/3, stamp located on the right-hand exterior of the cabinet.

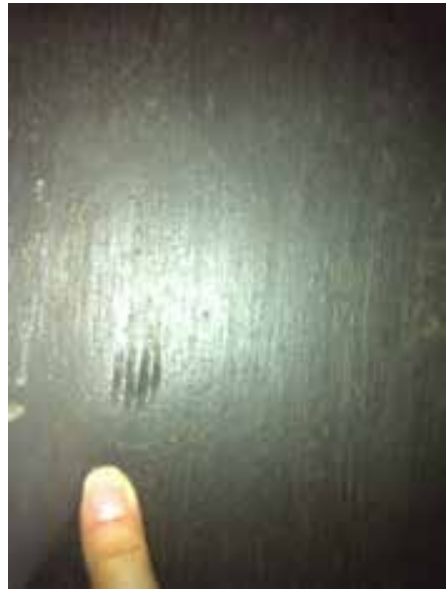

Fig. 26-right "Drie palen" stamps from central cabinets of Besloten Hofjes. Right: Mechelen Musea \& Erfgoed, BH/6, stamp located on the left-hand exterior of the cabinet.

\section{Where To?: New Investigative Paths}

The revised premise about the manufacture of the Mechelen hofjes offered here obliges a fresh conception of the hospital sisters' activities in the visual arts. This new model emphasizes patronage and reception rather than production. In that regard, I will argue in a future article that the reform-related Crucifixion hofje from the hospital, which dates to c. 1525-28, was commissioned by Cornelia Andries, the community's "moeder" (mother, a role akin to abbess) during the early years of the reforms. ${ }^{91}$ Four individuals with their patron saints are depicted in the hofje's wings, two on the interior (fig. 27) and two on the exterior (fig. 28). They are identified by inscriptions that include their administrative roles in the reform that was initiated at the hospital with the statues of 1509. ${ }^{92}$ Cornelia appears on the interior right-hand wing, with Peeter Van Steenwinckel, the first "rentmeester" (financial steward) on the left; Sister Sozijne Van Coolene appears on the right wing of the exterior, with Marten Avonts, the second "rentmeester" after the reforms (that is, Peeter Van Steenwinckel's successor), on the left.

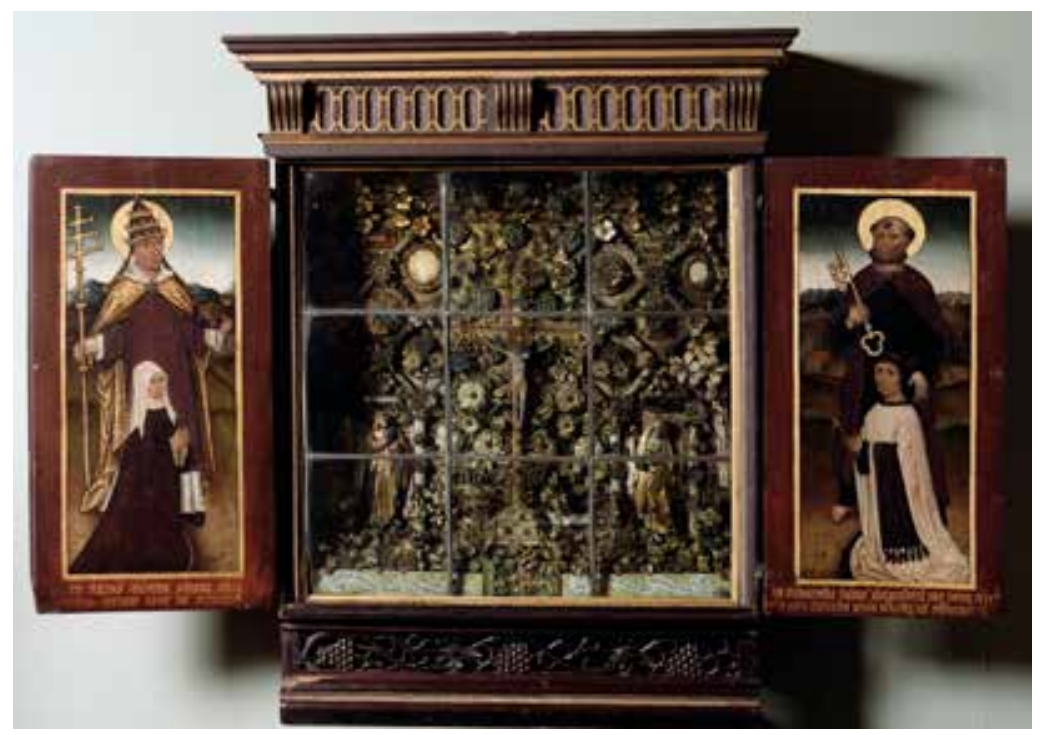

Fig. 27 Crucifixion Hofje, overview of center cabinet and wings, oil on panel, $109 \times 151.5 \times 19.5 \mathrm{~cm}$ (see fig. 2423),. ๑ KIK-IRPA, Brussels, www.kikirpa.be, cliché KN008410, photo: Jean-Luc Elias 


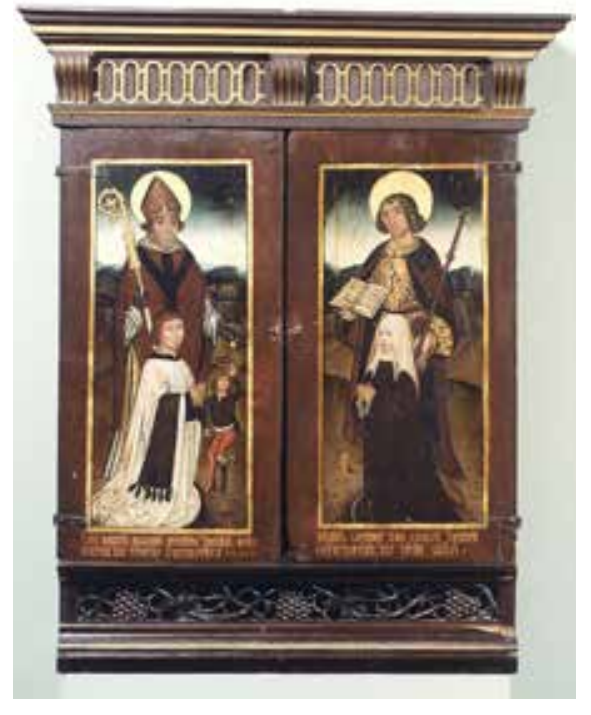

Fig. 28 Crucifixion Hofje, exterior wings, oil on panel, $109 \times 89.7 \mathrm{~cm}$ (see fig. 2423), @ KIK-IRPA, Brussels, www.kikirpa.be, cliché KM009587, photo: Jean-Luc Elias

Among my conclusions in that article is that the hofje emphasized the durability of the reforms during a potentially disruptive transitional period in its leadership, after the death of Peeter and the appointment of Marten. The hofje mediated with its internal audiences to keep the reform's leadership, values, and practices alive in the collective memory of the institution. This emphasis on internal conventual life is also apparent in the Saint Anne hofje, which includes portraits of two women who wear habits, both in the right-hand wing (fig. 29). I had surmised preliminarily,

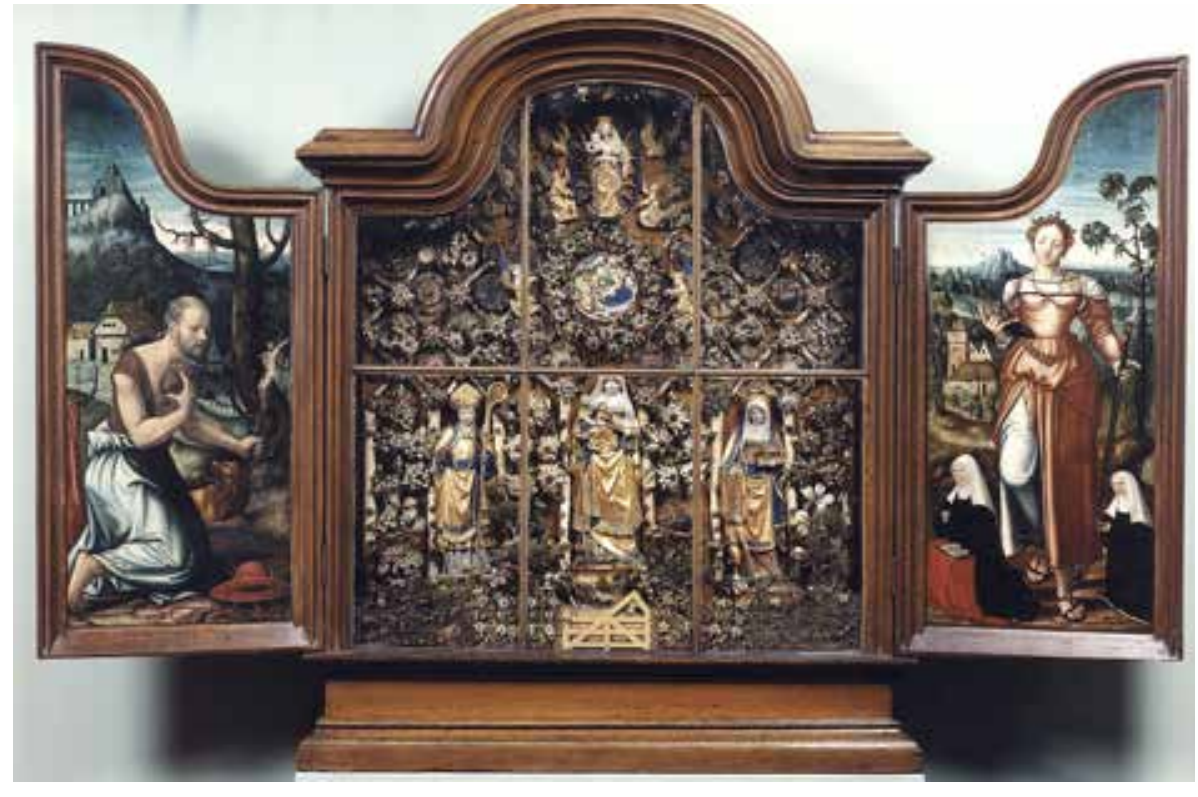

Fig. 29 Besloten Hofje with Saint Anne, the Virgin Mary, and the Christ Child (Sint-Anna-ten-drieën), Saint Augustine, and Saint Elisabeth, overview of center cabinet and wings, $150 \times 120$ $x 38 \mathrm{~cm}$, @ KIK-IRPA, Brussels, www. kikirpa.be, cliché KN008402, photo: Jean-Luc Elias (see fig. 25)

with considerable caution, that they are Catharien Van den Putte and Catelyn Van den Putte, both of whom professed in 1529. The choice of Saint Catherine to appear with them makes sense as a namesake saint for both women. Saint Catherine appears between and gesturing toward both sisters, albeit slightly favoring by her glance the sister depicted in the place of greater privilege, closest to the holy garden (the reason for Saint Jerome's appearance on the left-hand panel, for 
which no viable explanations have been offered, may eventually be explained with more research into the sisters' spirituality). It is possible that Catharien and Catelyn were related not only to each other but also to Jacob Van den Putte and Margaretha Svos. ${ }^{93}$ However, when observing the panels afresh in January of 2017 after their cleaning, it is now clear that the two sisters are depicted in very dark gray or black habits, not the brown habits of the Mechelen hospital. Furthermore, technical studies have revealed that the two figures were later additions, which also may in part account for their diminutive scale. ${ }^{94}$ Perhaps, then, this hofje was not destined for the hospital at its inception but came into the community later. Whatever the case, the internal nature of these other hofjes is markedly different from the external concerns represented by the Van den Putte/Svos hofje, presented by a lay couple on behalf of their daughter's and their own salvation. Study of the latter reveals by point of contrast the profound socio-religious complexities that underlie such works, complexities that we have now begun to recognize and understand.

39 Several other investigative paths remain open for the future. The scholarly landscape could benefit from more interdisciplinary, collaborative work on hofjes and on Netherlandish conventual art in general, including projects that bring art historians and cultural historians together with conservators and materiality specialists, as with the conservation project for the hofjes and the exhibition at the M-Museum Leuven. Art-historical inquiry could also intersect more deeply with the social sciences and with other humanities disciplines. In terms of the hofjes, disability specialists have called for integrating metaphorical disability with the lived experiences of disabled persons, as we have seen. By linking these areas of inquiry with the Van den Putte/Svos hofje, I hope to have shown the value of such investigation.

Similarly, it is important to attend to the specific characters of women's religious communities, to make clearer distinctions between the lived experiences of women in contemplative convents and those in working communities. Women in the former rather than the latter were simply more likely to have time to produce works of art. If we had understood earlier that the Mechelen sisters' obligations toward the infirm left them little if any opportunity to make handwork of the type represented by the gardens, we may have realized sooner that not just the painted wings but also the gardens were likely produced in professional settings or in contemplative convents.

41 Furthermore, Margaret of Austria's commissioning of a hofje from Galilea highlights the need to explore more fully the relationships between laywomen and professed women as they relate to visual culture and, as well, to identify and explore networks of religious women, both inside and outside specific religious orders. For example, Jan Pascha, the spiritual advisor for the Mechelen hospital sisters starting with the reforms, also advised contemplative Carmelite nuns at Onze-Lieve-Vrouw-ten-Troost (Our Lady of Consolation) at nearby Vilvoorde. Under Pascha's guidance, the Mechelen sisters were granted permission to practice Carmelite spirituality in 1519. ${ }^{95}$ The nuns at Vilvoorde were active producers of devotional woodcuts (for example, fig. 30), and perhaps some of the prints made their way to the Mechelen hospital and into the sisters' devotional practices.

To better understand these and other issues pertaining to religious women and their lives, about whom sometimes comparatively little was written or has survived, we must consider all the evidence at hand: visual, material, and textual. Finally, more work needs to be done with issues 


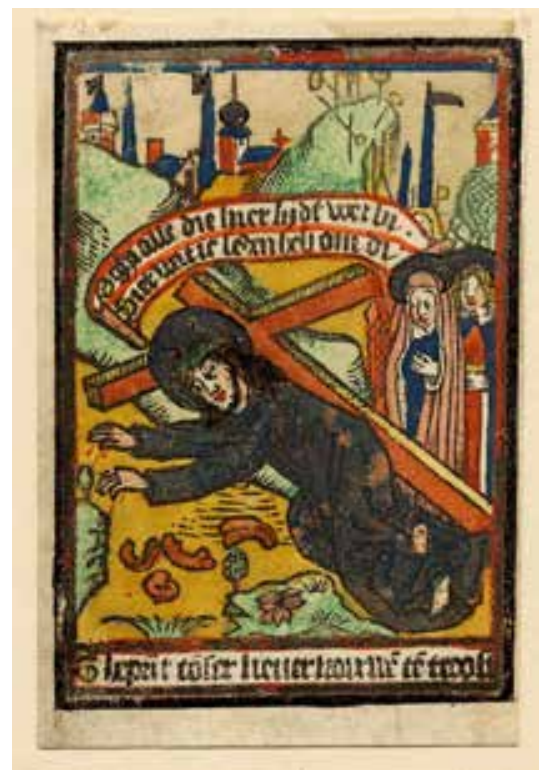

Fig. 30 Sisters at Onze-Lieve-Vrouwe-ten-Troost, Vilvoorde, Christ Falling under the Cross, 1500-20, hand-colored woodcut print, $10.7 \times 7.5 \mathrm{~cm}$. London, The British Museum, (c) The Trustees of the British Museum, inv. 1895,0122.5 (artwork in the public domain)

of gender in the patronage, production, and reception of Besloten hofjes. The Van den Putte/ Svos hofje and the reform-related Crucifixion hofje depict not only women but also men. While much is understood about the relationship between women and enclosed garden imagery, the hofjes ask us to consider the male perspective as well. Indeed, it was not only some women but also some men for whom the enclosed garden's references to purity were meaningful: hagiographic sources identify sexual abstinence as a practice of some saintly men, after whom some early modern Netherlandish men modeled their own behavior. ${ }^{96}$ Such questions suggest the distance to which modern scholars must reach to appreciate the complex social dimensions of the Besloten hofjes.

\section{Acknowledgements}

This project has accrued many debts; it is my pleasure to acknowledge them here at long last. I thank Sister Myriam, of the former Onze-Lieve-Vrouwegasthuis in Mechelen, and Louis Van Buggenhout, Ann Snauwaert, and Chris Andries for facilitating my visit with her. For access to the hofjes and archival materials in Mechelen, I am grateful to Wim Hüsken at the Mechelen Musea \& Erfgoed; Gerrit Vanden Bosch of the Archief van het Aartsbisdom Mechelen-Brussel; Willy Van de Vijver, De Ware Vrienden, and members of the staff of the Stadsarchief Mechelen; and Joni de Mol. The essay benefitted from discussions that followed my presentations at the National Gallery of Art in Washington, D.C., in 2014 and at the conference, "Considering Women in the Early Modern Low Countries," organized by Sarah Moran and Amanda Pipkin in Antwerp in 2015. I thank as well Kim Butler Wingfield, Cynthia Newman Edwards, Dagmar Eichberger, Heidi Eyestone, Reindert Falkenburg, Ingrid Falque, Aaron Hyman, Lynn F. Jacobs, Alison M. Kettering, Ann M. Roberts, Bret Rothstein, Kathryn M. Rudy, Mark Trowbridge, Joke Vandermeersch, Lieve Watteeuw, Diane Wolfthal, sisters of the Carmel "Troost" Vilvoorde, and the anonymous readers for JHNA. 
Andrea Pearson specializes in the study of women, gender, and sexuality in the early modern Low Countries. Her first book, Envisioning Gender in Burgundian Devotional Art, 1350-1530: Experience, Authority, Resistance, published by Ashgate in 2005, was awarded Honorable Mention for Best First Book by the Society for Medieval Feminist Scholarship. She is the editor of Women and Portraits in Early Modern Europe, published by Ashgate in 2008. Her essays have appeared in journals such as Art History, Gesta, Renaissance Quarterly, and The Sixteenth Century Journal, and in a number of edited volumes. Her current book project explores the moral implications of depicted gardens in the early modern Low Countries. She is an associate professor of art history at American University in Washington, D.C.

pearson@american.edu

\section{List of Illustrations}

Fig. 1 Mechelen, Besloten Hofje with Saint Elizabeth of Hungary, Saint Ursula, and Saint Catherine of Alexandria, 1513-24 (?) (center cabinet), polychromed wood, silk, paper, bone, wax, wire, and other materials in a wood case, 134 x 97.5 x $22.2 \mathrm{~cm}$. Musea \& Erfgoed Mechelen, inv. GHZ BH/2, Collectie Gasthuiszusters, Onze-Lieve-Vrouw Waver (artwork in the public domain; photo: () KIK-IRPA, Brussels, http://www.kikirpa.be)

Fig. 2 Bone relic of the 11,000 virgin martyrs labeled, "This comes from the bones of the 11,000 martyred [virgins] (Dit es tghebennte vande[n] $\mathrm{xi}^{\mathrm{m}}$ merteleere[n])” (detail of fig. 1) (Photo: () KIK-IRPA, Brussels, www.kikirpa.be, cliché X002679, photographer: Jean-Luc Elias)

Fig. 3 Detail fig. of 1

Fig. 4 Overview of center cabinet (see fig. 1) and wings, oil on panel, 134 x $188.5 \times 22.2 \mathrm{~cm}$.

Fig. 5 Right-hand wing (Maria Van den Putte) (detail of fig. 4) (Photo: (C KIK-IRPA, Brussels, www.kikirpa.be, cliché X002660, photographer: Jean-Luc Elias)

Fig. 6 Left-hand wing (Jacob Van den Putte with Saint James the Greater) and right-hand wing (Margaretha Svos and Maria Van den Putte with Saint Margaret of Antioch) (details of fig. 4) (Photo: (C) KIK-IRPA, Brussels, www.kikirpa.be, clichés X002659 and X002660, photographer: Jean-Luc Elias)

Fig. 7 Hans Memling, Triptych of Willem Moreel and Barbara Van Valenderberch, 1484, oil on panel, 41 x $174 \mathrm{~cm}$ (center); 141 x $87 \mathrm{~cm}$ (wings). Bruges, Groeninge Museum, inv. 0000. GRO0091.I-0095.I (artwork in the public domain; photo: (C) Lukas - Art in Flanders VZW, photographer: Hugo Maertens, https://creativecommons.org/licenses/by-nc-nd/4.0/legalcode)

Fig. 8 G. Braun and F. Hogenberg, Plan of the City of Mechelen, from Civitates Orbis Terrarum, Liber primus (Cologne, 1574). Mechelen, Stadsarchief, Beeldbankmechelen.be, inv. B.6522. 1) Residence of Jacob Van den Putte and Margaretha Svos, on Hanswijkstraat at the corner of Potterijstraat. 2) Onze-Lieve-Vrouwegasthuis. 
Fig. 9 Plan of Onze-Lieve-Vrouwegasthuis, Mechelen (detail). Mechelen, Stadsarchief, Beeldbankmechelen.be, iconografische verzameling, inv. C 8018.

Fig. 10 Wax medallion with the Resurrection, dated 1513 (detail of fig. 1) (Photo: (c) KIK-IRPA, Brussels, www.kikirpa.be, cliché X002683, photographer: Jean-Luc Elias)

Fig. 11 Attributed to the Master of Antwerp, Christ Heals Two Blind Men and a Mad Man, from Ludolph of Saxony, Tboeck vanden leven ons heeren Jesu Christi (The book of the life of our Lord Jesus Christ) (Zwolle [?], 1485-91), hand-colored woodcut, 9.2 x 12.4 cm. Amsterdam, Rijksmuseum, inv. RP-P-1961-717 (artwork in the public domain)

Fig. 12 Master of Alkmaar, Polyptych with the Seven Works of Charity, 1504, oil on panel, $119.1 \mathrm{x}$ $469.5 \mathrm{~cm}$ (with frame). Amsterdam: Rijksmuseum, inv. SK-A-2815, purchased with the support of the Vereniging Rembrandt and the Commissie voor Fotoverkoop (artwork in the public domain)

Fig. 13 Distributing Bread to the Blind and Needy (detail of fig. 12), oil on panel, $103.5 \mathrm{~cm} \times 55$ $\mathrm{cm}$. Amsterdam, Rijksmuseum, inv. SK-A-2815-1 (artwork in the public domain)

Fig. 14 Circle of Master of the Figdor Deposition (Utrecht), Crucifixion (detail), 1505, oil on panel, $104.1 \mathrm{~cm} \times 84.9 \mathrm{~cm}$. Amsterdam, Rijksmuseum, inv. SK-A-2212 (artwork in the public domain)

Fig. 15 Netherlandish, Christ and the Soul in the Garden of Gethsemane, from Die geestelicke boomgaert der vruchten daer die devote siel haer versadicht vanden vruchten der passien Christi (The spiritual fruit garden where the devout soul is satiated with the fruit of Christ's Passion), woodcut from an edition printed in Utrecht by Jan Bernsten, 1521. The Hague, Koninklijke Bibliotheek, inv. $150 \mathrm{G} \mathrm{44}$, fol. $17 \mathrm{r}$ (artwork in the public domain)

Fig. 16 Mechelen, Christ Child, ca. 1500, polychromed wood, gold, alabaster, velvet, ermine, pearls, and other materials, h. $30.5 \mathrm{~cm}$. Schwerin, Staatliches Museum (artwork in the public domain; photo: (C) Staatliches Museum Schwerin, photographer: Hugo Maertens)

Fig. 17 Netherlandish (?), The Hand as the Mirror of Salvation, 1466, hand-colored woodcut, 39.1 x 27 cm. Washington, D.C., National Gallery of Art, Rosenwald Collection, inv. 1943.3.639 (artwork in the public domain)

Fig. 18 Jan Mombaer, Chiropsalterium (Handpsalter), from Rosetum exercitiorum spiritualium et sacrarum meditationum (Rosary of spiritual exercises and sacred meditations) (Zwolle, 1510), woodcut, 19.7 x $14.5 \mathrm{~cm}$. Washington, D.C., Library of Congress, Music Division, ML171.M19 Case, n.p. (artwork in the public domain)

Fig. 19 German, Jocasta and Oedipus, from Giovanni Boccaccio, De mulieribus claris, (Ulm: Johann Zainer, 1473), woodcut, fol. 25v. Washington, D.C., Library of Congress, Rosenwald Collection, inv. Incun. 1473.B7 (artwork in the public domain)

Fig. 20 North Netherlands or Flanders, Immaculate Virgin, ca. 1480-1500, ivory with traces of 
polychrome, h. $11.3 \mathrm{~cm}$. Amsterdam, Rijksmuseum, inv. BK-2008-69, purchased with the support of the Frits en Phine Verhaaff Fonds/Rijksmuseum Fonds (artwork in the public domain)

Fig. 21 Jawbone relic labeled, "This is from the bones of the 11,000 virgins (Dit es ghebe[e]nte vande[n] xim mechde[n])," (detail of fig. 1)

Fig. 22 Hans Memling, Saint Ursula Shrine, 1489, oil and gilt on wood, 99 x 91.5 x $41.5 \mathrm{~cm}$. Bruges, St. John's Hospital (artwork in the public domain; photo: (C) Lukas - Art in Flanders VZW, photographer: Hugo Maertens, https://creativecommons.org/licenses/by-nc-nd/4.0/legalcode)

Fig. 23 Mechelen (?), Crucifixion Hofje, ca. 1510-30, polychromed wood, silk, paper, bone, wire, paint, and other materials in a wood case, 158.5 x 139 x $33 \mathrm{~cm}$. Musea \& Erfgoed Mechelen, inv. BH/1, Collectie Gasthuiszusters, Onze-Lieve-Vrouw Waver, (artwork in the public domain; photo: (C) KIK-IRPA, Brussels, www.kikirpa.be, cliché KN008407, photographer: Jean-Luc Elias)

Fig. 24 Mechelen, Crucifixion Hofje (central cabinet), ca. 1525-28, polychromed wood, silk, paper, bone, wire, paint, and other materials in a wood case, 109 x 89.7 x $19.5 \mathrm{~cm}$. Musea \& Erfgoed Mechelen, inv. BH/3, Collectie Gasthuiszusters, Onze-Lieve-Vrouw Waver (artwork in the public domain; photot: (C KIK-IRPA, Brussels, www.kikirpa.be, cliché KN008410, photographer: JeanLuc Elias)

Fig. 25 Mechelen, Besloten Hofje with Saint Anne, the Virgin Mary, and the Christ Child (SintAnna-ten-drieën), Saint Augustine, and Saint Elisabeth (center cabinet), 1529 (?), polychromed wood, silk, paper, bone, wax, wire, and other materials in a wood case, $150 \times 120$ x $38 \mathrm{~cm}$. Musea \& Erfgoed Mechelen, inv. BH/6, Collectie Gasthuiszusters, Onze-Lieve-Vrouw Waver (artwork in the public domain; photo: (C KIK-IRPA, Brussels, www.kikirpa.be, cliché KN008403, photographer: Jean-Luc Elias)

Fig. 26 "Drie palen" stamps from central cabinets of Besloten Hofjes. Left: Mechelen Musea \& Erfgoed, BH/3, stamp located on the right-hand exterior of the cabinet. Right: Mechelen Musea \& Erfgoed, $\mathrm{BH} / 6$, stamp located on the left-hand exterior of the cabinet

Fig. 27 Crucifixion Hofje, overview of center cabinet and wings, oil on panel, $109 \times 151.5$ x 19.5 cm (see fig. 24) (Photo: (C KIK-IRPA, Brussels, www.kikirpa.be, cliché KN008410, photographer: Jean-Luc Elias)

Fig. 28 Crucifixion Hofje, exterior wings, oil on panel, 109 x $89.7 \mathrm{~cm}$ (see fig. 24), (Photo: (C) KIK-IRPA, Brussels, www.kikirpa.be, cliché KM009587, photographer: Jean-Luc Elias)

Fig. 29 Besloten Hofje with Saint Anne, the Virgin Mary, and the Christ Child (Sint-Anna-tendrieën), Saint Augustine, and Saint Elisabeth, overview of center cabinet and wings, $150 \times 120 \times 38$ cm (see fig. 25) (Photo: (C) KIK-IRPA, Brussels, www.kikirpa.be, cliché KN008402, photographer: Jean-Luc Elias)

Fig. 30 Sisters at Onze-Lieve-Vrouwe-ten-Troost, Vilvoorde, Christ Falling under the Cross, 1500- 
20, hand-colored woodcut print, 10.7 x $7.5 \mathrm{~cm}$. London, The British Museum, inv. 1895,0122.5 (artwork in the public domain; photo: (C) The Trustees of the British Museum)

Unless otherwise indicated, translations are mine.

${ }^{1}$ Most of the relics are wrapped with bits of paper and wire; many are labeled with authentiques, small paper banderoles with inscriptions that declare the objects' authenticity.

${ }^{2}$ See E. Ann Matter, The Voice of My Beloved: The Song of Songs in Western Medieval Christianity (Philadelphia: University of Pennsylvania Press, 1990), xxiv-xxv.

${ }^{3}$ Among the first to use the term, although in its French counterpart Jardin clos, was Camille Poupeye, "Les jardins clos et leurs rapports avec la sculpture Malinoise," Bulletin du Cercle archéologique, littéraire et artistique de Malines 22 (1912): 50-114. See also, in addition to the publications cited below, Felix Marcus, "Die Mechelener 'Jardin Clos," Der Cicerone: Halbmonatsschrift für die Interessen des Kunstforschers \& Sammlers, ed. Georg Biermann (Leipzig: Klinkhardt \& Biermann, 1913), 98-101; Albert Marinus, "Le Jardin Clos," in Le Folklore Belge (Brussels: Les éditions historiques/Turnhout: Brepols, 1937), 3:234-57; and Paul Dony, "Les 'Jardins Clos," Ecclesia 98 (May 1957): 119-26. Not every work described as a Besloten hofje is equipped with a fence in the lower foreground, yet I would suggest that its absence would not preclude beholders from reading the work as an enclosed garden.

${ }^{4}$ Recent studies on Netherlandish visual practices in a devotional context include Andrea Pearson, "Visuality, Morality, and Same-Sex Desire: The Infants Christ and St. John the Baptist in Early Netherlandish Art," Art History 38, no. 3 (2015): 434-61; Mitzi Kirkland-Ives, In the Footsteps of Christ: Hans Memling's Passion Narratives and the Devotional Imagination in the Early Modern Netherlands (Turnhout: Brepols: 2013); Ingrid Falque, "Portraits de dévots, pratiques religieuses et expérience spirituelle dans la peinture des anciens Pays-Bas (1400-1550)" (PhD diss., University of Liège, 2009), to be published in revised form as Devotional Portraiture and Spiritual Experience in Early Netherlandish Painting (Leiden: Brill, forthcoming); John Decker, The Technology of Salvation and the Art of Geertgen tot Sint Jans (Aldershot: Ashgate, 2009); essays in Image and Imagination of the Religious Self in Late Medieval and Early Modern Europe, ed. R. L. Falkenburg, W. S. Melion, and T. M. Richardson (Turnhout: Brepols, 2007); and two works by Bret Rothstein, Sight and Spirituality in Early Netherlandish Painting (Cambridge: Cambridge University Press, 2005) and "Gender and the Configuration of Early Netherlandish Devotional Skill," in Women and Portraits in Early Modern Europe: Gender, Agency, Identity, ed. Andrea Pearson (Aldershot: Ashgate, 2008), 15-34.

${ }^{5} \mathrm{I}$ am grateful to Wim Hüsken for drawing this possibility to my attention during a conversation in 2013 at the Huis De Zalm in Mechelen, where the hofje was temporarily displayed. The sister does not seem to have the same affliction as any of the figures in Pieter Bruegel's Parable of the Blind Leading the Blind (1569). See Zeynel A. Karcioglu, "Ocular Pathology in The Parable of the Blind Leading the Blind and Other Paintings by Pieter Bruegel," Survey of Ophthamology 47, no. 1 (Jan.-Feb. 2002): 55-62. Her visage may indicate that she suffers from microphthalmia, a disorder in which the eyeballs are atypically small. I am grateful to Dr. Charles Pearson, O.D., for this information.

${ }^{6}$ Allison P. Hobgood and David Houston Wood, for example, have called for more work that 
"determine[s] how, precisely, medieval people viewed disability and how they rectified their religious views with the reality of corporeal difference." Allison P. Hobgood and David Houston Wood, eds., Recovering Disability in Early Modern England (Columbus: The Ohio State University Press, 2013), 14. I am aware that some authors use the terms disability and impairment differently, as does Irina Metzler in Disability in Medieval Europe: Thinking about Physical Impairment during the High Middle Ages, c. 1100-1400 (New York: Routledge, 2006) and A Social History of Disability in the Middle Ages: Cultural Considerations of Physical Impairment (New York: Routledge, 2013). A critique is offered by Joshua R. Eyler, ed., Disability in the Middle Ages: Reconsiderations and Reverberations (Burlington, Vt.: Ashgate, 2010). For a historical overview of disability issues in the Netherlands, see Ben Wuyts, Over Narren, Kreupelen, Doven en Blinden: Leven met een Handicap, van de Oudheid tot $\mathrm{Nu}$ (Leuven: Davidsfonds, 2005).

${ }^{7}$ Paul Vandenbroeck, "Tu meffleures," in Hooglied: De beeldwereld van religieuze vrouwen in de Zuidelijke Nederlanden, vanaf de 13de eeuw/Le jardin clos de l'ame: L'imaginaire des religieuses dans les Pays-Bas du Sud depuis le 13e siècle, ed. Paul Vandenbroeck, exh. cat. (Brussels: Paleis voor Schone Kunsten/Martial et Snoeck, 1994), 91-104. The relationship of the hofjes to conventual cloistering and paradise as discussed by Vandenbroeck were taken up again by Jeffrey F. Hamburger, Petra Marx, and Susan Marti, “The Time of the Orders, 1200-1500: An Introduction," in Crown and Veil: Female Monasticism from the Fifth to the Fifteenth Centuries, ed. Jeffrey F. Hamburger and Susan Marti (New York: Columbia University Press, 2008), 59-61. See also Erik Vandamme, "Het 'Besloten Hofje' in het Koninklijk Museum voor Schone Kunsten te Antwerpen: Bijdrage tot de studie van de kunstnijverheid in de provinciale Zuidnederlandse centra omstreeks 1500," in Archivum Artis Lovaniense: Bijdragen tot de Geschiedenis van de Kunst der Nederlanden; Opgedragen aan Prof. Em. Dr. J. K. Steppe, ed. Maurits Smeyers (Leuven: Peeters, 1981), 143-49. ${ }^{8}$ Barbara Baert, with an epilogue by Lise De Greff, "The Glorified Body," in Backlit Heaven: Power and Devotion in the Archdiocese of Mechelen (Tielt: Lannoo, 2009), 140-41. Essays from Hoogleid (see above, note 7): Luce Irigaray, "La voie du féminin, 155-65; Julia Kristeva, "Le Bonheur des beguines," 167-77; and Birgit Pelzer, "Reliquats," 179-203. Historicizing the hofjes offers an alternative to the psychoanalytic model, which presumes a universal female experience independent of the historical moment. See the critique of the essays in Hooglied by Liz James, "Hysterical (Hi)stories of Art," Oxford Art Journal 18, no.1 (1995): 143-47, who wrote: "How foolish of me to think that feminist theory had got us past the stage where the woman is mystical, emotional, spiritual, and hysterical" and "[i]t is considerably easier to describe female spirituality as wild and free ... than it is to consider medieval holy women in the context of their time" (145).

${ }^{9}$ Barbara Baert, "Echoes of Liminal Spaces: Revisiting the Late Mediaeval 'Enclosed Gardens' of the Low Countries (A Hermeneutical Contribution to Chthonic Artistic Expression)," Jaarboek Koninklijk Museum voor Schone Kunsten Antwerpen (2012): 40. See also Barbara Baert, "An Odour. A Taste. A Touch. Impossible to Describe': Noli Me Tangere and the Senses," in Religion and the Senses in Early Modern Europe, ed. Wietse de Boer and Christine Göttler (Leiden: Brill, 2013), 142-45; and Late Medieval Enclosed Gardens of the Low Countries: Contributions to Gender and Artistic Expression (Leuven: Peeters, 2016), which was published just as the present essay went to press.

${ }^{10}$ Kathryn M. Rudy, Virtual Pilgrimages in the Convent: Imagining Jerusalem in the Late Middle Ages (Turnhout: Brepols, 2011), 110-18 and 257-58.

${ }^{11}$ As discussed by W. Godenne, "Préliminaires à l'inventaire général des statuettes d’origine malinoise, présumées des $15^{\mathrm{e}}$ et $16^{\mathrm{e}}$ siècles," Handelingen van de Koninklijke Kring voor Oudheid- 
kunde, Letteren en Kunst van Mechelen 61 (1957): 110-16; A. Jansen, "Losse nota's over de merktekens op de Mechelse beeldjes (15e-16e eeuwen)," Koninklijke Kring voor Oudheldkunde Letteren en Kunst van Mechelen 66 (1962): 148-56; R. de Roo, "Mechelse Beeldhouwkunst," in Aspekten van de laatgotiek in Brabant: Tentoonstelling ingericht door de Intercommunale Interleuven ter gelegenheid van haar vijfarig bestaan (Leuven: Stedelijk Museum, 1971), 420-62; Jan Crab, Het Brabants Beeldsnijcentrum Leuven (Leuven: Stedelijk Museum Leuven, 1977); and Jan Crab, Het laatgotische beeldsnijcentrum Leuven: Tentoonstelling, Leuven, Stedelijk Museum, 6 oktober-2 december 1979 (Leuven: Stedelijk Museum, 1979). The figures of saints Elizabeth of Hungary, Ursula, and Catherine of Alexander in the hofje addressed here are stamped on their socles, indicating their professional production in the city. The stamps are the letter $M$ and Doermael, probably the name of a Mechelen woodcarver. See Het laatgotische beeldsnijcentrum Leuven, no. XX.15, 421-23; and Vandenberghe, "Besloten Hofjes," 49.

${ }^{12}$ Aspects of this argument are proposed in different ways by, for instance, Vandenberghe, "Besloten Hofjes," 49; Baert, "Echoes of Liminal Spaces," 11; and Rudy, Virtual Pilgrimages in the Convent, 112-18.

${ }^{13}$ Horst Appuhn, “Die Paradiesgärtlein des Klosters Ebstorf," Lüneburger Blätter 19-20 (1968-69): 27-39.

${ }^{14}$ Hartmut Krohm, "Reliquienpräsentation und Blumengarten: Kunstgeschichtliche Bemerkungen zu den Schreinen in Kloster Bentlage," Westfalen 77 (1999): 23-52.

${ }^{15}$ Dagmar Eichberger, Leben mit Kunst, Wirken durch Kunst: Sammelwesen und Hofkunst unter Margarete von Österreich, Regentin der Niederlande (Turnhout: Brepols, 2002), 397-99.

${ }^{16}$ The community, founded in the thirteenth century, was dissolved in 1992. The hospital's history was addressed most recently in an exhibition catalogue, 800 jaar Onze-Lieve-Vrouwegasthuis: Uit het erfgoed van de Mechelse gasthuiszusters en het OCMW (Mechelen: Stedelijke Musea, 1998), with a bibliography of previous studies on 94-97.

${ }^{17}$ The works have been discussed together by Stéphane Vandenberghe, "Besloten Hofjes," in 800 jaar Onze-Lieve-Vrouwegasthuis, 49-57. They are on long-term loan from the Augustinian Sisters of Mechelen to the Mechelen Musea \& Erfgoed, where they have been assigned inventory numbers of $\mathrm{BH} / 1-\mathrm{BH} / 7$. Two small recesses in each lateral side of the cabinet numbered $\mathrm{BH} / 1$ strongly suggest that wings were once hinged to this hofie, which is the largest and most frequently discussed example from the hospital. The right-hand wing of $\mathrm{BH} / 7$, dated 1539, includes a portrait of a kneeling male lay worshipper; the contents of the cabinet were replaced later, probably in the eighteenth century. An eighth hofie, $\mathrm{BH} / 8$, which dates to the nineteenth century, was also in the possession of the hospital sisters; see Backlit Heaven (see note 8 above), fig. 182. Two of the sixteenth-century works, $\mathrm{BH} / 2$ and $\mathrm{BH} / 3$, can be tied with relative certainty to the hospital during the era in which they were produced: they include portrait wings that depict identifiable individuals associated with the community at the time. One of these, $\mathrm{BH} / 2$, is discussed in the present study. $\mathrm{BH} / 3$ is the subject of a separate essay I am preparing for publication (portions of the argument are summarized below). The wings of $\mathrm{BH} / 4$ and $\mathrm{BH} / 5$ depict saints; portraits are not included.

${ }^{18}$ In addition to studies cited elsewhere in this essay, medieval Christian holy matter has received attention recently by Christy Anderson, Anne Dunlop, and Pamela H. Smith, eds., The Matter of Art: Materials, Practices, Cultural Logics, c. 1250-1750 (Manchester: Manchester University Press, 2015); Sara Ritchey, Holy Matter: Changing Perceptions of the Material World in Late Medieval Christianity (Ithaca: Cornell University Press, 2014); and Caroline Walker Bynum, Christian 
Materiality: An Essay on Religion in Late Medieval Europe (New York: Zone Books, 2011).

${ }^{19}$ See, for instance, Poupeye, "Les jardins clos," 79, and Vandenberghe, "Besloten Hofjes," 54, no. 49.

${ }^{20}$ The statutes are preserved in Mechelen at the Archief van het Aartsbisdom Mechelen-Brussel (hereafter AAB), Gasthuiszusters Mechelen 1, Statuten en ordonnanties, 1509. The passage referred to here is: "Neither novices nor professed sisters will be allowed to wear anything made of gold, silver, or silk, inside their habit or on top of it, so that all wealth is eschewed (En selen noch novicie[n]. noch geprofessyde. moighen hebben in hen abyt noch over hen draghen yet gewracht van goude silvere oft int syde[n]. om alle curieusheit te schouwene)," fol. 7r. My thanks to Gerrit Vanden Bosch, archivist at the AAB, for his assistance with accessing and interpreting this and other documents in the archive, and to Joni de Mol for providing an initial transcription of the preface of the statutes and for improving my translations that appear below. The original act of reform with the seal of Jacob de Crö̈, bishop of Cambrai, is preserved at the Stadsarchief Mechelen (hereafter SAM), with no catalog number. The AAB statues cited here are written in an early-sixteenth century hand and likely were in the possession of the hospital sisters in that period.

${ }^{21}$ After reaching this conclusion I found the same hypothesis in W. H. James Weale, Catalogue des objets d'art religieux du moyen âge, de la renaissance et des temps modernes: Exposés à l'Hotel Liedekerke à Malines, Septembre 1864 (Brussels: Charles Lelong, 1864), 38, no. 213. Weale's proposal, made over a century ago, disappeared from the literature, perhaps because it was difficult to imagine how or why a triptych representing laypersons would be present in a community of professed sisters, despite the semipublic nature of their work with the infirm.

${ }_{22}^{2}$ On names and naming in the later Middle Ages, see R. N. Swanson, Religion and Devotion in Europe, c. 1215-c. 1515 (Cambridge: Cambridge University Press, 1995), 168-70.

${ }^{23}$ The couple's testament was signed and notarized on April 9, 1524, "in the city of Mechelen, at our house that stands on Hanswijkstraat at the corner of Potterijstraat (inder stadt van Mechelen ten huyse van en selven ouders staende inde Hanswijck strate opden hoeck van de Putterijen)." SAM, OCMW 3094. My appreciation to Willy Hendrickx, Willem Miseur, and François van der Jeught, of De Ware Vrienden van het Archief, for transcribing and talking with me about this document, and about SAM, OCMW 3102 (schepenbrief) and 8804 (register) cited below. I thank Willy van de Vijver and the SAM staff for permitting access to these and other materials at the archive, and De Ware Vrienden for helping me to better understand the organization and content of the hospital's registers.

24 "These are donations and interest [receipts] belonging to the Holy Ghost of Hanswijk, for which this book was made and maintained by Jacob Van den Putte and Jacob de Vos, masters of the Holy Ghost, in the year of our lord 1523 (Dits den chijs en[de] de rente toebehoere[n]de heyligen gheest va[n] hanswijc. waer af dit boeck ghemaect en[de] v[er]nieut bi Jacob va[n]de[n] putte en[de] Jacob de Vos heylichgeestmeest[er]s Int Jaer o[n]s hee[re]n xv ${ }^{\mathrm{d}}$ en[de] xxiii)." SAM, P. Onze-Lieve-Vrouw van Hanswijk, Serie 1, no. 3, fol. 1 (numbered 5 in the upper right-hand corner).

${ }^{25}$ SAM, OCMW 3094.

${ }^{26}$ SAM, OCMW 3102. The children's names are, in addition to Maria, Jacob and Jan.

${ }^{27}$ SAM, OCMW 8804, f. 109r.

${ }^{28} \mathrm{I}$ have found no evidence for patronage and gifting in the materials at SAM or the AAB. 29 "[the] sculpture that was standing in the nuns' refectory ([de] beelde. dat sij nonne[n] reefter 
hebben staende)." AAB, Gasthuiszusters Mechelen 1, Statuten en ordonnanties, 1509, fol. 9v. ${ }^{30}$ Falque, "Portraits de dévots, pratiques religieuses," 104-5. Portraits that depict devotees with closed or nearly closed eyes are: the Master of the von Groote Adoration's Triptych of the Lamentation (Vienna, Gemäldegalerie der Akademie des bildenden Künste), the Master of Frankfurt's Triptych of the Humbracht Family (Frankfurt, Städelsches Kunstinstitut), and Joos van Ghent's Crucifixion with a Family at Prayer (Madrid, Collection Herreros de Tejada). A few other examples depict a worshipper looking down at a holy figure such that the eyes can seem closed but probably are not, as in a south-Netherlandish painting, The Nativity with a Monk in Prayer (Philadelphia, Lasalle University Art Museum). I thank Dr. Falque for sharing images and information from her catalogue with me.

${ }^{31}$ I thank Ingrid Falque for this suggestion.

${ }^{32}$ Ludolph of Saxony's Tboeck was widely read prior to the production of the hofje: it was published in four editions in Antwerp alone between 1487 and 1510.

${ }^{33}$ For examples of this iconography, see Ruth Mellinkoff, Outcasts: Signs of Otherness in Northern European Art of the Late Middle Ages (Berkeley: University of California Press, 1993), vol. 2, figs. VI.46-47; and David S. Areford, The Art of Empathy: The Mother of Sorrows in Northern Renaissance Art and Devotion (London and Jacksonville, Fla.: GILES for the Cummer Museum of Art and Gardens, 2013), 26, fig. 19. For Longinus, see Louis Réau, Iconographie de l'Art Chrétien, vol. 3, pt. 2, Iconographie des Saints (Paris: Presses Universitaires de France, 1958), 812-15.

${ }^{34}$ The IRR study was unveiled at a special showing of hofjes at the Museum Hof van Busleyden in Mechelen on January 11, 2017. My thanks to Lieve Watteeuw for discussing the results of the study with me.

${ }^{35}$ My thanks to Kim Butler Wingfield for drawing this connection to my attention.

${ }^{36}$ As in, for example, the right-hand wing of Hugo van der Goes's Portinari Altarpiece of ca. 1475 (Florence, Uffizi).

${ }^{37}$ Such tensions are discussed further in Pearson, "Visuality, Morality, and Same-Sex Desire (see note 4 above).

${ }^{38}$ Lindsey Row-Heyveld, “The lying'st knave in Christendom': The Development of Disability in the False Miracle of St. Alban's," Disability Studies Quarterly 29, no. 4 (Fall 2009): n.p.: http:// dsq-sds.org/article/view/994/1178.

${ }^{39}$ J. P. Filedt Kok, “De zeven werken van barmhartigheid, Meester van Alkmaar, 1504," Rijksmuseum, Amsterdam: hdl.handle.net/10934/RM0001.COLLECT.9048; and Henk van Os et al., Netherlandish Art in the Rijksmuseum: 1400-1600 (Zwolle: Waanders, 2000), 15-16 and 82-83.

${ }^{40}$ Larry Silver and Henry Luttikhuizen, “The Quality of Mercy: Representations of Charity in Early Netherlandish Art," Studies in Iconography 29 (2008): 216-48 (inscription on 223).

${ }^{41} \mathrm{New}$ work in medieval disability studies is revealing that both positive and negative perspectives on disabilities and the disabled sat side-by-side, as discussed by Eyler in the introduction to Disability in the Middle Ages (see note 6 above), 1-8. The visual evidence presented here, which has yet to be tapped by historians of disability, supports this claim.

${ }_{42}$ Augustine, The Trinity (De Trinitate), trans. with introduction and notes by Edmund Hill (Brooklyn, N.Y.: New City Press, 1991), XI.i.2. For a recent analysis of medieval writings on the senses, including Augustine's, see Éric Palazzo, L' invention chrétienne des cinq sens dans la liturgie et l'art au Moyen âge (Paris: Les Éditions du Cerf, 2014), 59-90.

${ }^{43}$ Augustine's argument cannot be addressed in depth here. For a recent analysis with additional bibliography, see Eugene Vance, "Seeing God: Augustine, Sensation, and the Mind's Eye," in 
Rethinking the Medieval Senses: Heritage/Fascinations/Frames, ed. Stephen G. Nichols, Andreas Kablitz, and Alison Calhoun (Baltimore: The Johns Hopkins University Press, 2008), 13-29; and Alice E. Sanger and Siv Tove Kulbrandstad Walker, eds., Sense and the Senses in Early Modern Art and Cultural Practice (Farnham, U.K.: Ashgate, 2012), 1-16.

${ }^{44}$ See the discussion by Edward Wheatley, "Blind' Jews and Blind Christians: The Metaphorics of Marginalization," chap. 3, in Stumbling Blocks Before the Blind: Medieval Constructs of Disability (Ann Arbor: University of Michigan Press, 2010), 63-89 with notes on 237-43. See also Moche Barasch, Blindness: The Story of a Mental Image in Western Thought (New York: Routledge, 2001), and Kahren Jones Hellerstedt, “The Blind Man and His Guide in Early Netherlandish Painting," Simiolus: Netherlands Quarterly for the History of Art 13 (1983): 163-81.

${ }^{45}$ For a deeper discussion of the complex imagery of the Rohan Hours miniatures, and the moralizing text paired with them, see Mellinkoff, Outcasts, 1:114-15.

${ }^{46}$ Mellinkoff, Outcasts, 1:115.

${ }^{47}$ See Baert, "Echoes of Liminal Spaces," 9-25, for a discussion that draws from different primary sources than those cited here.

${ }^{48}$ Reindert M. Falkenburg, The Fruit of Devotion: Mysticism and the Imagery of Love in Flemish Paintings of the Virgin and Child, 1450-1550 (Amsterdam: John Benjamins Publishing, 1994), 42-46.

${ }^{49}$ For these practices, see Annette LeZotte, "Cradling Power: Female Devotions and Early Netherlandish Jésueaux," in Push Me, Pull You: Physical and Spatial Interaction in Late Medieval and Renaissance Art, ed. Sarah Blick and Laura D. Gelfand (Leiden: Brill, 2011), 59-84. My thanks to Dagmar Eichberger for bringing the Christ Child to my attention. Much has been written on art and the women's monastic context in Germany. See, for example, the studies by Jeffrey F. Hamburger, Nuns as Artists: The Visual Culture of a Medieval Convent (Berkeley: University of California Press, 1997) and The Visual and the Visionary: Art and Female Spirituality in Late Medieval Germany (New York: Zone Books/Cambridge, Mass.: MIT Press, 1998).

${ }^{50}$ Claire Richter Sherman, Writing on Hands: Memory and Knowledge in Early Modern Europe, exh. cat. (Carlisle, Penn.: Dickinson College, Trout Gallery; Washington, D.C.: Folger Shakespeare Library /Seattle: University of Washington Press, 2000), 64, and Areford, The Art of Empathy, 53.

${ }^{51}$ As interpreted by Sherman, Writing on Hands, 246-47.

${ }^{52}$ Wheatley, "Blinding, Blindness, and Sexual Transgression," chap. 5 in Stumbling Blocks before the Blind, 129-54 and 248-51.

${ }_{53}$ Margaret Franklin, Boccaccio's Heroines: Power and Virtue in Renaissance Society (Aldershot, U.K.: Ashgate, 2006), 101n93. For a translation of Boccaccio's text: Famous Women, ed. Virginia Brown (Cambridge: Harvard University Press, 2001). See also P. F. J. Obbema et al., Boccaccio in Nederland: Tentoonstelling van handschriften en gedrukte werken uit het bezit van Nederlandse bibliotheken ter herdenking van het zeshonderdste sterfiaar van Boccaccio (1313-1375) (Leiden: Academisch Historisch Museum, 1975).

${ }^{54}$ The panel is discussed in "Keuze uit de aanwinsten. I: Paneeltje met Maria Immaculata," Bulletin van het Rijksmuseum 56, no. 4 (2008): 474-75. The complex associations between garden imagery and sexuality in the early modern Netherlands was discussed recently by Pearson, "Visuality, Morality, and Same-Sex Desire," 443-45. For an overview of critical issues in the study of enclosed gardens, see Liz Herbert McAvoy, “The Medieval Hortus conclusus: Revisiting the Pleasure Garden," Medieval Feminist Forum 50,no. 1 (2014): 5-10.

${ }^{55}$ For example, "it benefits religious women to be cut off from the company of secular persons, 
and particularly from men. Therefore, to avoid a habitual and daily entrance of secular people, as in other, well-regulated convents, divisions shall be made (want den religieusen vrouwen betaept vanden gemeynschape der weerlijcker persoone[n] ende besonder der mannen. afgesneden ende $\mathrm{v}$ [er]vrempt te sijne. dair omme om te schouwene den gewoenlijck en daigelijcsschen inganck der weerlijcker personen. na maniere vanden anderen wel gereguleerden conventen. salmen maken slutingen)." AAB, Gasthuiszusters Mechelen 1, Statuten en ordonnanties, 1509, fols. 15r-15v. ${ }^{56}$ Heverlee (Leuven), Abdij van Park, Ms. 18, 115r-125v, transcribed and assigned a provenance with the Geel sisters by Kathryn M. Rudy, "How to Prepare the Bedroom for the Bridegroom," in Frauen-Kloster-Kunst: Neue Forschungen zur Kulturgeschichte des Mittelalters, ed. Carola Jaeggi, Hedwig Roeckelein, and Jeffrey F. Hamburger (Turnhout: Brepols, 2007), 369-75. For a manuscript with a Mechelen calendar that may have belonged to a sister at the Onze-Lieve-Vrouwegasthuis in Mechelen (Ms. 71 G 53, Koninklijke Bibliotheek, The Hague), see Kathryn M. Rudy, "Dirty Books: Quantifying Patterns of Use in Medieval Manuscripts Using a Densitometer," JHNA: Journal of Historians of Netherlandish Art 2, nos. 1-2 (2010): 8-10, DOI: 10.5092/ jhna.2010.2.1.1. The reform of the Geel hospital by Mechelen sisters is discussed by Frieda Van Ravensteyn, "Het hospitaal van Geel van zijn ontstaan tot 1552," in 450 jaar Gasthuiszusters Augustinessen van Geel, ed. Frieda Van Ravensteyn, Michel De Bont, and Jaak Segers (Geel: St.-Dimpna- en Gasthuismuseum, 2002), 14-15.

57 “[P]ainted with a virginal green (met scoender groender verwen)." Heverlee (Leuven), Abdij van Park, Ms. 18, 115v.

${ }^{58}$ Sharon T. Strocchia, "Introduction" in "Women and Healthcare in Early Modern Europe," ed. Sharon T. Strocchia, special issue, Renaissance Studies 28, no. 4 (Sept. 2014): 499.

${ }^{59}$ Naoë Kukita Yoshikawa, "The Virgin in the Hortus conclusus: Healing the Body and Healing the Soul," Medieval Feminist Forum 50, no. 1 (2014): 11-32. For recent perspectives and bibliography on women and healthcare, see Monica Green, "Gendering the History of Women's Healthcare," Gender and History 20 (2008): 487-518; Alisha Rankin, "Women in Science and Medicine, 14001800," in The Ashgate Research Companion to Women and Gender in Early Modern Europe, ed. Allyson M. Poska, Jane Couchman, and Katherine A. McIver (Farnham, U.K.: Ashgate, 2013), 407-21; and Strocchia, "Introduction," 496-514.

${ }^{60}$ Carole Rawcliffe, "Delectable Sightes and Fragrant Smelles': Gardens and Health in Late Medieval and Early Modern England," Garden History 37 (2008): 6.

${ }^{61}$ See Falkenburg, The Fruit of Devotion, 42-46, with additional examples.

${ }^{62}$ Yoshikawa, "The Virgin in the Hortus conclusus," 18.

${ }^{63}$ My thanks to Wim Hüsken for providing access to the hofje at the Hof van Busleyden in Mechelen in July of 2014, which enabled me to catalogue the relics and transcribe the authentiques. Evidence of pin or nail holes in the lateral inner sides of the cabinet indicate that at least these areas of the hofje were subject to manipulation sometime in the past.

${ }^{64}$ Among recent studies on relics are James Robinson and Lloyd de Beer, eds., with Anna Harnden, Matter of Faith: An Interdisciplinary Study of Relics and Relic Veneration in the Medieval Period (London: The British Museum, 2014); Cynthia Hahn, Strange Beauty: Issues in the Making and Meaning of Reliquaries, 400-circa 1204 (University Park: Pennsylvania State University Press, 2012); Charles Freeman, Holy Bones, Holy Dust: How Relics Shaped the History of Medieval Europe (New Haven: Yale University Press, 2011); Martina Bagnoli et al., eds., Treasures of Heaven: Saints, Relics, and Devotion in Medieval Europe, exh. cat. (Cleveland Museum of Art; Baltimore: Walters Art Museum; London: The British Museum/New Haven: Yale University Press, 2010); Backlit 
Heaven (see note 8 above); and Henk W. van Os, The Way to Heaven: Relic Veneration in the Middle Ages (Baarn: de Prom, 2000), with reference to the Van den Putte hofje on p. 32.

${ }^{65}$ The texts of several authentiques are partly obscured by the garden's sculptural elements and therefore could not be read in full. The conservation project discussed below will enable the authentiques to be catalogued.

${ }^{66}$ See Jeanne Nuechterlein, "Hans Memling's St. Ursula Shrine: The Subject as Object of Pilgrimage," in Art and Architecture of Late Medieval Pilgrimage in Northern Europe and the British Isles, ed. Sarah Blick and Rita Tekippe (Leiden: Brill, 2005), 62.

${ }^{67}$ Jacobus de Voragine, The Golden Legend: Readings on the Saints, trans. William Granger Ryan (Princeton: Princeton University Press, 1993), 2:259-60.

${ }^{68}$ For rosaries, see John R. Decker, “Practical Devotion': Apotropaism and the Protection of the Soul," in The Authority of the Word: Reflecting on Image and Text in Northern Europe, 1400-1700, ed. Celeste Brusati, Karl A. E. Enenkel, and Walter S. Melion (Boston: Brill, 2009), 371-75; for coral, see Peter Parshall, ed., The Woodcut in Fifteenth-Century Europe (Washington, D.C.: National Gallery of Art, 2009), 158.

${ }^{69}$ Monica Green, "Bodies, Gender, Health, Disease: Recent Work on Medieval Women's Medicine," Studies in Medieval and Renaissance History 4 (2005): 1-46, uses the term "agents of heath" to account for the many ways in which women were active medical providers, including situations such as household illness management in which they did not hold formal positions.

${ }^{70}$ I draw here primarily from the introduction to Juan Luis Vives, De subventione pauperum sive de humanis necessitatibus, Libri II: Introduction, Critical Edition, Translation and Notes, ed. Charles Fantazzi and Constantinus Matheeussen, with the assistance of J. de Landtsheer (Leiden: Brill, 2002). See also Andrew Cunningham and Ole Peter Grell, Health Care and Poor Relief in Protestant Europe, 1500-1700 (London: Routledge, 1997); Thomas Safley, ed. The Reformation of Charity: The Secular and the Religious in Early Modern Poor Relief (Leiden: Brill, 2003); James Brodman, Charity and Religion in Medieval Europe (Washington, D.C.: Catholic University of America Press, 2009); Andrew Brown, "Civic Charity," in Civic Ceremony and Religion in Medieval Bruges c. 1300-1520 (Cambridge, : Cambridge University Press, 2012), 195-221; Jane Kromm, "The Early Modern Lottery in the Netherlands: Charity as Festival and Parody," in Parody and Festivity in Early Modern Art: Essays on Comedy as Social Vision, ed. David R. Smith (Farnham, U.K.: Ashgate 2012), 51-62; and Anne M. Scott, "Experiences of Charity: Complex Motivations in the Charitable Endeavour, c. 1100-c. 1650," in Experiences of Charity, 1250-1650, ed. Anne M. Scott (Farnham, U.K.: Ashgate, 2015), 1-14.

${ }^{71}$ Fantazzi and Matheeussen, "Introduction," in Vives, De subventione pauperum, $\mathrm{x}-\mathrm{xi}$. See also Juan Luis Vives, The Origins of Modern Welfare: Juan Luis Vives, De Subventione Pauperum, and City of Ypres, Forma Subventionis Pauperum, trans. with notes and commentary by Paul Spicker (Oxford: Peter Lang, 2010), and Juan Luis Vives, On Assistance to the Poor, trans. with introduction and commentary by Alice Tobriner (Toronto: University of Toronto Press in association with the Renaissance Society of America, 1999).

${ }^{72}$ Vives, De subventione pauperum, 97.

${ }^{73}$ Vives, De subventione pauperum, 105.

${ }^{74}$ See the state of the question in Scott, "Experiences of Charity," 1-14.

75 "diverse gebreken aende vrouwe ende nonne[n] des voirseiden gasthuys. soe int onderhouden van huer religie. Regule en[de] drie geloften bij hen geproffesijt. Soe oic int besor[g]h. dienst. en $[\mathrm{de}]$ bewaringhe. vanden siecke[n] aldair ligghende. ende sunderlinge mede inde vuytwindin- 
heit. en[de] manieren van huen habijten te draghene. meer nader weerelt dan nader religien.” AAB, Gasthuiszusters Mechelen 1, Statuten en ordonnanties, 1509, fol. 1r.

76 "Nochtans en hadden sij dat alsoe nijet gedae[n] noch achteruolght. maer ware[n] dair jnne seere gebreckelic geweest en[de] noch sijn. hadden oick nijet allee[n] die voirseide statute[n]. ende ordinancien"; "dat oick de selve vrouwe ende nonnen dat alsoe nae huer beste hadde[n] beloeft te doen." AAB, Gasthuiszusters Mechelen 1, Statuten en ordonnanties, 1509, fol. 1v. 77 "Maer huer religie en[de] discipline int voirseide gasthuys bynne[n] onsen tijde[n] meer v[er] acht. vergheten. en [de] achter gelaten. en $[\mathrm{de}] \mathrm{he}[\mathrm{m}]$ qualicker inder armen dienst gequeten dan te vore[n]. alle ten swaren last. en[de] perijckel van hure[n] sielen. en[de] ten grooten achterdeele. en[de] schade des voirseide[n] gasthuys. en[de] ongerief vanden armen. en[de] siecken." AAB, Gasthuiszusters Mechelen 1, Statuten en ordonnanties, 1509, fol. 1v.

${ }^{78}$ Naemlyst der Zusters van O.-L.-V. Gasthuis, der Zusters van O.-L.-V. Gasthuis, sedert hare Stichting, binnen Mechelen (Mechelen: H. Dierickx-Beke, 1862), 4. The original list, from which the published version was produced, remains in the possession of the sisters who were professed at the community before its dissolution in 1992. I thank Sister Myriam for showing it to me in 2014 and Louis Van Buggenhout for facilitating our conversation. The hofje is inv. BH/3, Mechelen Musea \& Erfgoed; see below for inscriptions in the hofje that identify the figures.

${ }^{79}$ It is not known precisely where the hofjes were displayed, but perhaps they were in the nuns' choir adjacent to the church proper, which is evidenced in a nineteenth-century plan of the hospital (SAM C 8018; see the detail reproduced as fig. 9 above). The plan and structures were modified occasionally, as, for instance, when the infirmary was enlarged in the second half of the sixteenth century. See the discussion by Jaak Ockeley, "Het Onze-Lieve-Vrouwegasthuis te Mechelen van de stichting tot het begin van de negentiende eeuw," in 800 jaar Onze-Lieve-Vrouwegasthuis, 7-23, with an overview of the plan illustrated on p. 5. See also Ockeley's study on the hospital in the seventeenth and eighteenth centuries, which includes some material on the period under consideration here: De gasthuiszusters en hun ziekenzorg in het aarsbisdom Mechelen in de 17de en de 18de eeuw: Bijdrage tot de studie van de actieve vrouwelijke kloostercongregaties (Brussels: Archives et bibliothèques de Belgique, 1992).

${ }^{80}$ Rudy, Virtual Pilgrimages in the Convent, 115. Baert's discussion of sensory experience built on Rudy's interest in this issue, particularly in regard to smell and touch invoked by the gardens' floral adornments. See Baert, "Echoes of Liminal Spaces," 20-25; and “'An Odour. A Taste. A Touch. Impossible to Describe," 142-45.

${ }^{81}$ Eichberger, Leben mit Kunst, 397-99, with documentation.

${ }^{82}$ AAB, Gasthuiszusters Mechelen 1, Statuten en ordonnanties, 1509, fols. 19r-19v.

${ }^{83}$ I found no evidence of hofjes or their materials in the following registers: SAM OCMW 8797 (1494-1507), 8798 (1507-11), 8799 (1511-18), 8800 (1518-23), 8801 (1523-26), 8802 (1533), 8803 (1534-37), 8804 (1537-43), and 8805 (1543-54). Registers for the years 1527-32 are not present in the archive. My thanks to De Ware Vrienden of the Archief for helping me to navigate the books.

${ }^{84}$ Personal correspondence with Kathryn Rudy.

${ }^{85}$ Officially on October 19, 1520, with permission granted by Charles V. See SAM, OCMW 8763, with reference in a historical account of the hospital titled, "Onze Lieve Vrouwgasthuis te Mechelen," 206, composed anonymously by its sisters in the early twentieth century. I thank Wim Hüsken and Gerrit Vanden Bosch for providing me with copies of the manuscript.

${ }^{86}$ SAM, OCMW 8800, fol. 74v: "It[em] beth[aelt] van eender nieuwen croone[n] ghemaect van 
wasse ende bloemen die inden reefter hanct bove[n] de tafele xii st[uiver]s (Item, paid for a new crown, made of wax and flowers, which hangs in the refectory above the table, 12 stuivers)."

Translation by De Ware Vrienden of the Archief.

${ }^{87}$ Mechelen Musea \& Erfgoed, inv. BH/1, as evidenced by carved recesses for hinges, now missing, in the exterior lateral sides of the cabinet.

${ }^{88}$ The conservation team is led by Joke Vandermeersch and Lieve Watteeuw. The first results of the project are discussed in a forthcoming article: Joke Vandermeersch and Lieve Watteeuw, "De conservering van de 16de-eeuwse Mechelse Besloten Hofjes: Een interdisciplinaire aanpak voor historische mixed media," in Postprints 8ste BRK-APROA/Onroerend Erfgoed Colloquium: Innovatie in de conservatie-restauratie (Brussels, November 12-13, 2015). I thank Joke Vandermeersch for providing the citation.

${ }^{89}$ In 2013 the hofjes were installed in the Huis De Zalm in Mechelen in ways that limited visual and physical access. Additional stamps will perhaps emerge under different conditions.

${ }^{90}$ An example of the drie palen of Mechelen appears in Crab, Het Brabants Beeldsnijcentrum Leuven, 62, pl. 19. See also Lynn F. Jacobs, Early Netherlandish Carved Altarpieces, 1380-1550: Medieval Tastes and Mass Marketing (Cambridge: Cambridge University Press, 1998), esp. 15561.

${ }^{91}$ Mechelen Musea \& Erfgoed, inv. BH/3. I presented aspects of this argument at "Early Modern Women: New Perspectives," a conference held at the University of Miami in 2013; at the Sixteenth Century Society and Conference in 2013; and at the National Gallery of Art, Washington, D.C., in 2014. An essay on this hofje is in progress.

92 "Zuster cornelia andries vander Reformatien die ierste moeder; Heer peeter van Steenwinckele vander reformation die ierste rintmeester die gebuerde altera innocentū anno $\mathrm{xv}^{\mathrm{c}}$ viii; Zuster sozijne van Coolen[e] vander Reformatien die ierste zuster; Heer marten avonts priestere vander Reformatien die tweede Rintmeestere (Sister Cornelia Andries, the first mother of the reform; Sir Peeter van Steenwinckel, the first financial steward of the reform, which was begun on the Day of the Innocents in the year 1508; Sister Sozijne van Coolene, the first sister of the reform; Sir Marten Avonts, priest of the reform and second financial steward)."

${ }^{93}$ The names "Catharien Van den Putte" and "Catelyn Van den Putte" appear with their dates of profession in Naemlyst, 5-6.

${ }_{94}$ As conveyed to me by Joke Vandermeersch.

${ }^{95}$ Letter of 1519 from Fr. Bernardinus de Senis, cited in AAB, “Onze Lieve Vrouwgasthuis te Mechelen," 206.

${ }^{96}$ For the monastic context, see John Van Engen, Sisters and Brothers of the Common Life: The Devotio Moderna and the World of the Later Middle Ages (Philadelphia: University of Pennsylvania Press, 2008), 157-61. See also Andrea Pearson, Envisioning Gender in Burgundian Devotional Art, 1350-1530: Experience, Authority, Resistance (Aldershot, U.K.: Ashgate, 2005), esp. 90-135.

\section{Bibliography}

\section{Archival and Manuscript Sources}

Mechelen, Archief van het Aartsbisdom Mechelen-Brussel (AAB). Gasthuiszusters Mechelen 1, Statuten en ordonnanties, 1509. Statutes of reform, May 17, 1509. "Onze Lieve Vrouwgasthuis te 
Mechelen.” Manuscript. Historical account of the history of Onze-Lieve-Vrouwegasthuis composed by unidentified sisters, early twentieth century.

Mechelen, Stadsarchief (SAM). Archief van de COO. OCMW 3094. Testament of Jacob Van den Putte and Margaretha Svos, April 9, 1524. OCMW 3102. Testament of Jacob Van den Putte and Margaretha Svos, April 9, 1527 [1526]. OCMW 8763. Rights of Onze-Lieve-Vrouwegasthuis to property left by the deceased, October 19, 1520. OCMW 8797-8805. Rekeningen (financial registers), Onze-Lieve-Vrouwegasthuis, 1494-1554 (registers for 1527-32 are absent). OCMW 8775. Pitantieboek, Heilige Geesttafel van Hanswijk, 1523.

The Hague, Koninklijke Bibliotheek, Ms. 71 G 53 (prayer book).

Heverlee (Leuven), Abdij van Park, Ms. 18 (prayer book).

\section{Printed Sources}

Anderson, Christy, Anne Dunlop, and Pamela H. Smith, eds. The Matter of Art: Materials, Practices, Cultural Logics, c. 1250-1750. Manchester: Manchester University Press, 2015.

Appuhn, Horst. “Die Paradiesgärtlein des Klosters Ebstorf.” Lüneburger Blätter 19-20 (1968-69): 27-39.

Areford, David S. The Art of Empathy: The Mother of Sorrows in Northern Renaissance Art and Devotion. London and Jacksonville, Fla.: GILES for the Cummer Museum of Art and Gardens, 2013.

Augustine, The Trinity (De Trinitate). Translated with introduction and notes by Edmund Hill. Brooklyn, N.Y.: New City Press, 1991.

Baert, Barbara. "Echoes of Liminal Spaces. Revisiting the Late Mediaeval 'Enclosed Gardens' of the Low Countries (A Hermeneutical Contribution to Chthonic Artistic Expression)." Jaarboek Koninklijk Museum voor Schone Kunsten Antwerpen (2012): 9-46.

Late Medieval Enclosed Gardens of the Low Countries: Contributions to Gender and Artistic Expression. Leuven: Peeters, 2016.

“'An Odour. A Taste. A Touch. Impossible to Describe': Noli Me Tangere and the Senses." In Religion and the Senses in Early Modern Europe, edited by Wietse de Boer and Christine Göttler, 111-51. Leiden: Brill, 2013.

Baert, Barbara, with an epilogue by Lise De Greff. “The Glorified Body." In Backlit Heaven: Power and Devotion in the Archdiocese of Mechelen, 130-52. Tielt: Lannoo, 2009.

Bagnoli, Martina, et al., eds. Treasures of Heaven: Saints, Relics, and Devotion in Medieval Europe. Exh. cat. Cleveland Museum of Art; Baltimore: Walters Art Museum; London: The British Muse- 
um/New Haven: Yale University Press, 2010.

Barasch, Moche. Blindness: The Story of a Mental Image in Western Thought. New York: Routledge, 2001.

Boccaccio, Giovanni. Famous Women. Translated by Virginia Brown. Cambridge: Harvard University Press, 2001.

Brodman, James. Charity and Religion in Medieval Europe. Washington, D.C.: Catholic University of America Press, 2009.

Brown, Andrew. "Civic Charity." In Civic Ceremony and Religion in Medieval Bruges c. 1300-1520, 195-221. Cambridge: Cambridge University Press, 2012.

Bynum, Caroline Walker. Christian Materiality: An Essay on Religion in Late Medieval Europe. New York: Zone Books, 2011.

Crab, Jan. Het Brabants Beeldsnijcentrum Leuven. Leuven: Stedelijk Museum Leuven, 1977. . Het laatgotische beeldsnijcentrum Leuven: Tentoonstelling, Leuven, Stedelijk Museum, 6 oktober-2 december 1979. Leuven: Stedelijk Museum, 1979.

Cunningham, Andrew, and Ole Peter Grell, Health Care and Poor Relief in Protestant Europe, 1500-1700. London: Routledge, 1997.

Decker, John. "Practical Devotion': Apotropaism and the Protection of the Soul." In The Authority of the Word: Reflecting on Image and Text in Northern Europe, 1400-1700, edited by Celeste Brusati, Karl A. E. Enenkel, and Walter S. Melion, 357-84. Boston: Brill, 2009.

Decker, John. The Technology of Salvation and the Art of Geertgen tot Sint Jans. Aldershot, U.K.: Ashgate, 2009.

Dony, Paul. “Les ‘Jardins Clos.” Ecclesia 98 (May 1957): 119-26.

Eichberger, Dagmar. Leben mit Kunst, Wirken durch Kunst: Sammelwesen und Hofkunst unter Margarete von Österreich, Regentin der Niederlande. Turnhout: Brepols, 2002.

800 jaar Onze-Lieve-Vrouwegasthuis: Uit het erfgoed van de Mechelse gasthuiszusters en het OCMW. Exh, cat. Mechelen: Stedelijke Musea, 1998.

Eyler, Joshua R., ed. Disability in the Middle Ages: Reconsiderations and Reverberations. Burlington, Vt.: Ashgate, 2010.

Falkenburg, Reindert M. The Fruit of Devotion: Mysticism and the Imagery of Love in Flemish Paintings of the Virgin and Child, 1450-1550. Amsterdam: John Benjamins Publishing, 1994. 
Falkenburg, R. L., W. S. Melion, T. M. Richardson, eds. Image and Imagination of the Religious Self in Late Medieval and Early Modern Europe. Turnhout: Brepols, 2007.

Falque, Ingrid. "Portraits de dévots, pratiques religieuses et expérience spirituelle dans la peinture des anciens Pays-Bas (1400-1550).” PhD diss., University of Liège, 2009. Forthcoming as Devotional Portraiture and Spiritual Experience in Early Netherlandish Painting. Leiden: Brill.

Franklin, Margaret. Boccaccio's Heroines: Power and Virtue in Renaissance Society. Aldershot, U.K.: Ashgate, 2006.

Freeman, Charles. Holy Bones, Holy Dust: How Relics Shaped the History of Medieval Europe. New Haven: Yale University Press, 2011.

Godenne, W. "Préliminaires à l'inventaire général des statuettes d’origine malinoise, présumées des $15^{e}$ et $16^{e}$ siècles." Handelingen van de Koninklijke Kring voor Oudheidkunde, Letteren en Kunst van Mechelen 61 (1957): 47-127.

Green, Monica. "Bodies, Gender, Health, Disease: Recent Work on Medieval Women's Medicine." Studies in Medieval and Renaissance History 4 (2005): 1-46.

. "Gendering the History of Women’s Healthcare." Gender and History 20 (2008): 487-

518.

Hahn, Cynthia. Strange Beauty: Issues in the Making and Meaning of Reliquaries, 400-circa 1204. University Park: Pennsylvania State University Press, 2012.

Hamburger, Jeffrey F. Nuns as Artists: The Visual Culture of a Medieval Convent. Berkeley: University of California Press, 1997.

. The Visual and the Visionary: Art and Female Spirituality in Late Medieval Germany.

New York: Zone Books/Cambridge, Mass.: MIT Press, 1998.

Hamburger, Jeffrey F., Petra Marx, and Susan Marti. “The Time of the Orders, 1200-1500: An Introduction." In Crown and Veil: Female Monasticism from the Fifth to the Fifteenth Centuries, edited by Jeffrey F. Hamburger and Susan Marti, 41-75. New York: Columbia University Press, 2008.

Hellerstedt, Kahren Jones. "The Blind Man and His Guide in Early Netherlandish Painting." Simiolus: Netherlands Quarterly for the History of Art 13 (1983): 163-81.

Hobgood, Allison P., and David Houston Wood, eds. Recovering Disability in Early Modern England. Columbus: The Ohio State University Press, 2013.

Irigaray, Luce. "La voie du féminin." In Hooglied: De beeldwereld van religieuze vrouwen in de Zuidelijke Nederlanden, vanaf de 13de eeuw/Le jardin clos de l'ame: L'imaginaire des religieuses dans 
les Pays-Bas du Sud depuis le 13e siècle, edited by Paul Vandenbroeck, 155-65. Exh. cat. Brussels: Paleis voor Schonen Kunsten/Martial et Snoeck, 1994.

Jacobs, Lynn F. Early Netherlandish Carved Altarpieces, 1380-1550: Medieval Tastes and Mass Marketing. Cambridge: Cambridge University Press, 1998.

James, Liz. “Hysterical (Hi)stories of Art.” Oxford Art Journal 18, no. 1 (1995): 143-47.

Jansen, A. "Losse nota’s over de merktekens op de Mechelse beeldjes (15e-16e eeuwen)." Koninklijke Kring voor Oudheldkunde Letteren en Kunst van Mechelen 66 (1962): 148-56.

Karcioglu, Zeynel A. "Ocular Pathology in The Parable of the Blind Leading the Blind and Other Paintings by Pieter Bruegel." Survey of Ophthamology 47, no. 1 (Jan.-Feb. 2002): 55-62.

"Keuze uit de aanwinsten. I: Paneeltje met Maria Immaculata." Bulletin van het Rijksmuseum 56, no. 4 (2008): 474-75.

Kirkland-Ives, Mitzi. In the Footsteps of Christ: Hans Memling's Passion Narratives and the Devotional Imagination in the Early Modern Netherlands. Turnhout: Brepols, 2013.

Kok, J. P. Filedt. "De zeven werken van barmhartigheid, Meester van Alkmaar, 1504." Rijksmuseum, Amsterdam (hdl.handle.net/10934/RM0001.COLLECT.9048).

Kristeva, Julia. "Le Bonheur des beguines." In Hooglied: De beeldwereld van religieuze vrouwen in de Zuidelijke Nederlanden, vanaf de 13de eeuw/Le jardin clos de l'ame: L'imaginaire des religieuses dans les Pays-Bas du Sud depuis le 13e siècle, edited by Paul Vandenbroeck, 167-77. Exh. cat Brussels: Paleis voor Schonen Kunsten/Martial et Snoeck, 1994.

Krohm, Harmut. "Reliquienpräsentation und Blumengarten: kunstgeschichtliche Bemerkungen zu den Schreinen in Kloster Bentlage." Westfalen 77 (1999): 23-52.

Kromm, Jane. “The Early Modern Lottery in the Netherlands: Charity as Festival and Parody.” In Parody and Festivity in Early Modern Art: Essays on Comedy as Social Vision, edited by David R. Smith, 51-62. Farnham, U.K.: Ashgate 2012.

LeZotte, Annette. "Cradling Power: Female Devotions and Early Netherlandish Jésueaux.” In Push Me, Pull You: Physical and Spatial Interaction in Late Medieval and Renaissance Art, edited by Sarah Blick and Laura D. Gelfand, 59-84. Leiden: Brill, 2011.

Ludolph of Saxony. Tboeck vanden leven ons heeren Jesu Christi (The book of the life of our Lord Jesus Christ). Zwolle (?): Peter van Os, 1495.

Marcus, Felix. “Die Mechelener 'Jardin Clos.” In Der Cicerone: Halbmonatsschrift für die Interessen des Kunstforschers and Sammlers, edited by Georg Biermann, 98-101. Leipzig: Klinkhardt \& Biermann, 1913. 
Marinus, Albert. “Le Jardin Clos.” In Le Folklore Belge, vol. 3, 234-57. Brussels: Les éditions historiques/Turnhout: Brepols, 1937.

Matter, E. Ann. The Voice of My Beloved: The Song of Songs in Western Medieval Christianity. Philadelphia: University of Pennsylvania Press, 1990.

McAvoy, Liz Herbert. “The Medieval Hortus conclusus: Revisiting the Pleasure Garden.” Medieval Feminist Forum 50, no. 1 (2014): 5-10.

Mellinkoff, Ruth. Outcasts: Signs of Otherness in Northern European Art of the Late Middle Ages. 2 vols. Berkeley: University of California Press, 1993.

Metzler, Irina. Disability in Medieval Europe: Thinking about Physical Impairment during the High Middle Ages, c. 1100-1400. New York: Routledge, 2006.

. A Social History of Disability in the Middle Ages: Cultural Considerations of Physical Impairment. New York: Routledge, 2013.

Naemlyst der Zusters van O.-L.-V. Gasthuis, der Zusters van O.-L.-V. Gasthuis, sedert hare Stichting, binnen Mechelen. Mechelen: H. Dierickx-Beke, 1862.

Nuechterlein, Jeanne. "Hans Memling's St. Ursula Shrine: The Subject as Object of Pilgrimage." In Art and Architecture of Late Medieval Pilgrimage in Northern Europe and the British Isles, edited by Sarah Blick and Rita Tekippe, 51-75. Leiden: Brill, 2005.

Obbema, P. F. J., et al., Boccaccio in Nederland: Tentoonstelling van handschriften en gedrukte werken uit het bezit van Nederlandse bibliotheken ter herdenking van het zeshonderdste sterfjaar van Boccaccio (1313-1375). Leiden: Academisch Historisch Museum, 1975.

Ockeley, Jaak. De gasthuiszusters en hun ziekenzorg in het aarsbisdom Mechelen in de 17de en de 18de eeuw: Bijdrage tot de studie van de actieve vrouwelijke kloostercongregaties. Brussels: Archives et bibliothèques de Belgique, 1992.

. "Het Onze-Lieve-Vrouwegasthuis te Mechelen van de stichting tot het begin van de negentiende eeuw." In 800 jaar Onze-Lieve-Vrouwegasthuis: Uit het erfgoed van de Mechelse gasthuiszusters en het OCMW, 7-23. Mechelen: Stedelijke Musea, 1998.

Os, Henk W. van. The Way to Heaven: Relic Veneration in the Middle Ages. Baarn: de Prom, 2000.

Os, Henk W. van, Jan Piet Filedt Kok, Ger Luijten, and Frits Scholten. Netherlandish Art in the Rijksmuseum: 1400-1600. Zwolle: Waanders, 2000.

Palazzo, Éric. L' invention chrétienne des cinq sens dans la liturgie et l'art au Moyen âge. Paris: Les Éditions du Cerf, 2014. 
Parshall, Peter, ed. The Woodcut in Fifteenth-Century Europe. Washington, D.C.: National Gallery of Art, 2009.

Pearson, Andrea. Envisioning Gender in Burgundian Devotional Art, 1350-1530: Experience, Authority, Resistance. Aldershot, U.K.: Ashgate, 2005.

. "Visuality, Morality, and Same-Sex Desire: The Infants Christ and St. John the Baptist in Early Netherlandish Art." Art History 38, no. 3 (2015): 434-61.

Pelzer, Birgit. "Reliquats." In Hooglied: De beeldwereld van religieuze vrouwen in de Zuidelijke Nederlanden, vanaf de 13de eeuw/Le jardin clos de l'ame: L'imaginaire des religieuses dans les Pays-Bas du Sud depuis le 13e siècle, edited by Paul Vandenbroeck, 179-203. Exh. cat. Brussels: Paleis voor Schonen Kunsten/Martial et Snoeck, 1994.

Poupeye, Camille. "Les jardins clos et leurs rapports avec la sculpture Malinoise." Bulletin du Cercle archéologique, littéraire et artistique de Malines 22 (1912): 50-114.

Rankin, Alisha. "Women in Science and Medicine, 1400-1800." In The Ashgate Research Companion to Women and Gender in Early Modern Europe, edited by Allyson M. Poska, Jane Couchman, and Katherine A. McIver, 407-21. Farnham, U.K.: Ashgate, 2013.

Rawcliffe, Carole. “Delectable Sightes and Fragrant Smelles': Gardens and Health in Late Medieval and Early Modern England." Garden History 37 (2008): 3-21.

Réau, Louis. Iconographie de l'Art Chrétien. Paris: Presses Universitaires de France, 1958. Ritchey, Sara. Holy Matter: Changing Perceptions of the Material World in Late Medieval Christianity. Ithaca: Cornell University Press, 2014.

Robinson, James, and Lloyd de Beer, eds., with Anna Harnden. Matter of Faith: An Interdisciplinary Study of Relics and Relic Veneration in the Medieval Period. London: The British Museum, 2014.

Roo, R. de. "Mechelse Beeldhouwkunst." In Aspekten van de laatgotiek in Brabant: Tentoonstelling ingericht door de Intercommunale Interleuven ter gelegenheid van haar vijfarig bestaan, 420-62. Leuven: Stedelijk Museum, 1971.

Rothstein, Bret. "Gender and the Configuration of Early Netherlandish Devotional Skill.” In Women and Portraits in Early Modern Europe: Gender, Agency, Identity, edited by Andrea Pearson, 15-34. Aldershot, U.K.: Ashgate, 2008.

Rothstein, Bret. Sight and Spirituality in Early Netherlandish Painting. Cambridge: Cambridge University Press, 2005.

Row-Heyveld, Lindsey. “'The lying'st knave in Christendom’: The Development of Disability in the 
False Miracle of St. Alban's.” Disability Studies Quarterly 29, no. 4 (Fall 2009): n.p. (http://dsq-sds. org/article/view/994/1178).

Rudy, Kathryn M. "Dirty Books: Quantifying Patterns of Use in Medieval Manuscripts Using a Densitometer." JHNA: Journal of Historians of Netherlandish Art 2, nos. 1-2 (2010): 1-26 (DOI: 10.5092/jhna.2010.2.1.1).

"How to Prepare the Bedroom for the Bridegroom." In Frauen-Kloster-Kunst: Neue Forschungen zur Kulturgeschichte des Mittelalters, edited by Carola Jaeggi, Hedwig Roeckelein, and Jeffrey F. Hamburger, 369-75. Turnhout: Brepols, 2007.

. Virtual Pilgrimages in the Convent: Imagining Jerusalem in the Late Middle Ages.

Turnhout: Brepols, 2011.

Safley, Thomas, ed. The Reformation of Charity: The Secular and the Religious in Early Modern Poor Relief. Leiden: Brill, 2003.

Sanger, Alice E., and Siv Tove Kulbrandstad Walker, eds. Sense and the Senses in Early Modern Art and Cultural Practice. Farnham, U.K.: Ashgate, 2012.

Scott, Anne M. "Experiences of Charity: Complex Motivations in the Charitable Endeavour, c. 1100-c. 1650." In Experiences of Charity, 1250-1650, edited by Anne M. Scott, 1-14. Farnham, U.K.: Ashgate, 2015.

Sherman, Claire Richter. Writing on Hands: Memory and Knowledge in Early Modern Europe. Exh. cat. Carlisle, Penn.: Dickinson College, Trout Gallery; Washington, D.C.: Folger Shakespeare Library/Seattle: University of Washington Press, 2000.

Silver, Larry, and Henry Luttikhuizen. "The Quality of Mercy: Representations of Charity in Early Netherlandish Art." Studies in Iconography 29 (2008): 216-48.

Strocchia, Sharon T. "Introduction.” In "Women and Healthcare in Early Modern Europe." Special issue. Renaissance Studies 28, no. 4 (Sept. 2014): 496-514.

Swanson, R. N. Religion and Devotion in Europe, c. 1215-c. 1515. Cambridge: Cambridge University Press, 1995.

Van Engen, John. Sisters and Brothers of the Common Life: The Devotio Moderna and the World of the Later Middle Ages. Philadelphia: University of Pennsylvania Press, 2008.

Van Ravensteyn, Frieda. “Het hospitaal van Geel van zijn ontstaan tot 1552.” In 450 jaar Gasthuiszusters Augustinessen van Geel, edited by Frieda Van Ravensteyn, Michel De Bont, and Jaak Segers, 8-21 and 188. Geel: St.-Dimpna- en Gasthuismuseum, 2002.

Vance, Eugene. "Seeing God: Augustine, Sensation, and the Mind's Eye." In Rethinking the Medie- 
val Senses: Heritage/Fascinations/Frames, edited by Stephen G. Nichols, Andreas Kablitz, and Alison Calhoun, 13-29. Baltimore: The Johns Hopkins University Press, 2008.

Vandamme, Erik. "Het 'Besloten Hofje' in het Koninklijk Museum voor Schone Kunsten te Antwerpen: Bijdrage tot de studie van de kunstnijverheid in de provinciale Zuidnederlandse centra omstreeks 1500." In Archivum Artis Lovaniense: Bijdragen tot de Geschiedenis van de Kunst der Nederlanden; Opgedragen aan Prof. Em. Dr. J. K. Steppe, edited by Maurits Smeyers, 143-49. Leuven: Peeters, 1981.

Vandenberghe, Stéphane. “Besloten Hofjes.” In 800 jaar Onze-Lieve-Vrouwegasthuis: Uit het erfgoed van de Mechelse gasthuiszusters en het OCMW, 49-57. Exh. cat. Mechelen: Stedelijke Musea, 1998.

Vandenbroeck, Paul. “Tu m'effleures.” In Hooglied: De beeldwereld van religieuze vrouwen in de Zuidelijke Nederlanden, vanaf de 13de eeuw/Le jardin clos de l'ame: L'imaginaire des religieuses dans les Pays-Bas du Sud depuis le 13e siècle, edited by Paul Vandenbroeck, 13-153. Exh. cat. Brussels: Paleis voor Schonen Kunsten/Martial et Snoeck, 1994.

Vandermeersch, Joke, and Lieve Watteeuw. "De conservering van de 16de-eeuwse Mechelse Besloten Hofjes; Een interdisciplinaire aanpak voor historische mixed media." In Postprints 8ste BRK-APROA/Onroerend Erfgoed Colloquium: Innovatie in de conservatie-restauratie. Brussels, November 12-13, 2015.

Vives, Juan Luis. De subventione pauperum sive de humanis necessitatibus, Libri II: Introduction, Critical Edition, Translation and Notes. Edited by Charles Fantazzi and Constantinus Matheeussen, with the assistance of J. de Landtsheer. Leiden: Brill, 2002.

Vives, Juan Luis. On Assistance to the Poor. Translated with introduction and commentary by Alice Tobriner. Toronto: University of Toronto Press in association with the Renaissance Society of America, 1999.

Vives, Juan Luis. The Origins of Modern Welfare: Juan Luis Vives, De Subventione Pauperum, and City of Ypres, Forma Subventionis Pauperum. Translated with notes and commentary by Paul Spicker. Oxford: Peter Lang, 2010.

Voragine, Jacobus de. The Golden Legend: Readings on the Saints. Translated by William Granger Ryan. Princeton: Princeton University Press, 1993.

Weale, W. H. James. Catalogue des objets d'art religieux du moyen âge, de la renaissance et des temps modernes: Exposés à l'Hotel Liedekerke à Malines, Septembre 1864. Brussels: Charles Lelong, 1864.

Wheatley, Edward. Stumbling Blocks before the Blind: Medieval Constructs of Disability. Ann Arbor: University of Michigan Press, 2010.

Wuyts, Ben. Over Narren, Kreupelen, Doven en Blinden: Leven met een Handicap, van de Oudheid 
tot $N u$. Leuven: Davidsfonds, 2005.

Yoshikawa, Naoë Kukita. "The Virgin in the Hortus conclusus: Healing the Body and Healing the Soul." Medieval Feminist Forum 50, no. 1 (2014): 11-32.

Recommended Citation:

Andrea Pearson, "Sensory Piety as Social Intervention in a Mechelen Besloten Hoffe," Journal of Historians of Netherlandish Art 9:2 (Summer 2017) D0I: 10.5092/jhna.2017.9.2.1 